\title{
Tectonic exhumation of the Central Alps recorded by detrital zircon in the Molasse Basin, Switzerland
}

\author{
Owen A. Anfinson ${ }^{1,2}$, Daniel F. Stockli ${ }^{2}$, Joseph C. Miller ${ }^{3}$, Andreas Möller ${ }^{3}$, and Fritz Schlunegger ${ }^{4}$ \\ ${ }^{1}$ Department of Geology, Sonoma State University, Rohnert Park, CA 94928, USA \\ ${ }^{2}$ Department of Geological Sciences, Jackson School of Geoscience, University of Texas at Austin, Austin, TX 78712, USA \\ ${ }^{3}$ Department of Geology, University of Kansas, Lawrence, KS 66045, USA \\ ${ }^{4}$ Institute of Geological Sciences, University of Bern, 3012 Bern, Switzerland
}

Correspondence: Owen A. Anfinson (anfinson@sonoma.edu)

Received: 1 April 2020 - Discussion started: 29 April 2020

Revised: 13 August 2020 - Accepted: 2 October 2020 - Published: 23 November 2020

\begin{abstract}
Eocene to Miocene sedimentary strata of the Northern Alpine Molasse Basin in Switzerland are well studied, yet they lack robust geochronologic and geochemical analysis of detrital zircon for provenance tracing purposes. Here, we present detrital zircon U-Pb ages coupled with rareearth and trace element geochemistry to provide insights into the sedimentary provenance and to elucidate the tectonic activity of the central Alpine Orogen from the late Eocene to mid Miocene. Between 35 and $22.5 \pm 1 \mathrm{Ma}$, the detrital zircon $\mathrm{U}-\mathrm{Pb}$ age signatures are dominated by age groups of 300-370, 380-490, and 500-710 Ma, with minor Proterozoic age contributions. In contrast, from $21 \mathrm{Ma}$ to $\sim 13.5 \mathrm{Ma}$ (youngest preserved sediments), the detrital zircon $\mathrm{U}-\mathrm{Pb}$ age signatures were dominated by a 252-300 Ma age group, with a secondary abundance of the 380-490 Ma age group and only minor contributions of the 500-710 Ma age group. The Eo-Oligocene provenance signatures are consistent with interpretations that initial basin deposition primarily recorded unroofing of the Austroalpine orogenic lid and lesser contributions from underlying Penninic units (including the Lepontine dome), containing reworked detritus from Variscan, Caledonian-Sardic, Cadomian, and Pan-African orogenic cycles. In contrast, the dominant 252-300 Ma age group from early Miocene foreland deposits is indicative of the exhumation of Variscan-aged crystalline rocks from the Lepontine dome basement units. Noticeable is the lack of Alpine-aged detrital zircon in all samples with the exception of one late Eocene sample, which reflects Alpine volcanism linked to incipient continent-continent collision. In addition, detrital zircon rare-earth and trace element data, coupled with zircon
\end{abstract}

morphology and $\mathrm{U} / \mathrm{Th}$ ratios, point to primarily igneous and rare metamorphic sources.

The observed switch from Austroalpine to Penninic detrital provenance in the Molasse Basin at $\sim 21 \mathrm{Ma}$ appears to mark the onset of synorogenic extension of the Central Alps. Synorogenic extension accommodated by the Simplon fault zone promoted updoming and exhumation the Penninic crystalline core of the Alpine Orogen. The lack of Alpine detrital zircon $\mathrm{U}-\mathrm{Pb}$ ages in all Oligo-Miocene strata corroborate the interpretations that between $\sim 25$ and $15 \mathrm{Ma}$, the exposed bedrock in the Lepontine dome comprised greenschist-facies rocks only, where temperatures were too low for allowing zircon rims to grow, and that the Molasse Basin drainage network did not access the prominent Alpine-age Periadriatic intrusions located in the area surrounding the Periadriatic Line.

\section{Introduction}

Foreland basins archive the evolution of collisional mountain belts and can provide powerful insights into geodynamic processes operating in the adjacent mountain belt, as the stratigraphy of these basins directly records the history of subduction, thrusting, and erosion in the adjacent orogen (Jordan and Flemings, 1991; Sinclair and Allen, 1992; DeCelles and Giles, 1996). The Northern Alpine Foreland Basin in Switzerland, also known as the Swiss Molasse Basin, has long been the site of extensive research and helped define fundamental concepts applicable to other flexural foreland 
basins. Research has focused on sedimentary architecture and facies relationships (Diem, 1986; Platt and Keller, 1992; Kempf et al., 1999; Garefalakis and Schlunegger, 2019), biostratigraphy (Engesser and Mayo, 1987; Schlunegger et al., 1996; Kälin and Kempf, 2009; Jost et al., 2016), and magnetostratigraphy (Schlunegger et al., 1996; Schlunegger et al., 1997a; Kempf et al., 1999; Strunck and Matter, 2002). These studies significantly refined the reconstruction of depositional processes within a detailed temporal framework (Kuhlemann and Kempf, 2002) and yielded a more complete picture of the basin evolution in response to orogenic processes (Sinclair and Allen, 1992; Allen et al., 2013; Schlunegger and Kissling, 2015). In the same sense, attention has been paid to exploring the sedimentary provenance of the basin. However, available constraints from heavy-mineral assemblages (Fûchtbauer, 1964; Gasser, 1966, 1968; Schlanke, 1974; Schlunegger et al., 1997a; Kempf et al., 1999; von Eynatten, 2003) or clast suites of conglomerates (Habicht, 1945; Matter, 1964; Gasser, 1968; Stürm, 1973; Schlunegger et al., 1997a; Kempf et al., 1999) have largely been inconclusive in terms of sediment sourcing (von Eynatten et al., 1999). Yet, such insights are of critical importance for reconstructing the causal relationships between orogenic events and the basinal stratigraphic response. In the recent years, advances in isotopic provenance tracing techniques, including detrital mica ${ }^{40} \mathrm{Ar} /{ }^{39} \mathrm{Ar}$ dating (e.g., von Eynatten et al., 1999; von Eynatten and Wijbrans, 2003), zircon fission track dating of detrital clasts (Spiegel et al., 2000), detrital garnet and epidote geochemical analysis (Spiegel et al., 2002; Stutenbecker et al., 2019), and detrital zircon U-Pb geochronology (e.g., Malusà et al., 2016; Anfinson et al., 2016; Lu et al., 2018; Sharman et al., 2018a) have offered more quantitative links to Alpine geodynamic processes, revealed through seismic tomography imaging (Lippitsch et al., 2003; Fry et al., 2010; Hetényi et al., 2018) or bedrock geochronology (synthesized by Boston et al., 2017). In this study, we integrate high-density $\mathrm{U}-\mathrm{Pb}$ and trace and rare-earth element analysis of detrital zircon from the late-Eocene to mid-Miocene stratigraphic record of the Swiss Molasse Basin to elucidate the tectonic activity and unroofing history of the Central Alps. We particularly focused in detail on marine and non-marine Molasse deposits of the Lucerne area of central Switzerland (Fig. 1) directly north of the Lepontine dome - the preeminent crystalline core of the central European Alps that exposes Penninic units. These new results document that rapid tectonic unroofing or exhumation of these Penninic rocks in the Lepontine dome (Boston et al., 2017) resulted in a detectable provenance shift recorded in the foreland basin strata. While signals of this tectonic unroofing or exhumation have been previously documented within the Molasse (e.g., von Eynatten et al., 1999; Spiegel et al., 2000, 2001, 2004; Garefalakis and Schlunegger, 2019), we collected a highsample-density detrital zircon $\mathrm{U}-\mathrm{Pb}$ dataset from marine and non-marine Molasse sandstones near Lucerne (Fig. 1) at a temporal resolution of $<1 \mathrm{Ma}$, spanning $\sim 22.5$ to $19 \mathrm{Ma}$.
This early Miocene time interval is when a provenance shift was previously documented and we expect to see an abrupt or gradual detrital zircon provenance shift. We augmented the new high-resolution Lucerne dataset with detrital zircon $\mathrm{U}-\mathrm{Pb}$ ages from western and eastern sections near Thun in Switzerland and Bregenz in Austria (Fig. 1), respectively. While these complementary datasets are more limited in terms of temporal resolution, they allow us to explore lateral provenance variations. Overall, this new high-resolution detrital zircon $\mathrm{U}-\mathrm{Pb}$ dataset from the Northern Alpine Molasse Basin enables us to illuminate erosional processes, syntectonic drainage evolution, and linkages to the progressive tectonic unroofing of the orogenic hinterland in the Central Alps as well as to explore the influence of these tectonic processes on the long-term stratigraphic development of the Swiss Molasse Basin.

\section{The Central Alps: architecture and evolution}

\subsection{Architecture}

The continental collision between Adria, a promontory of the African plate, and the European plate resulted in the Cenozoic Alpine Orogen (Stampfli and Borel, 2002; Schmid et al., 2004). Convergence began with the subduction of European oceanic lithosphere beneath the Adriatic continental plate in the Late Cretaceous, resulting in the closure of the Alpine Tethys ocean (Schmid et al., 1996; Lihou and Allen, 1996) and culminating in the final continental collision, which started at $\sim 35 \mathrm{Ma}$ at the latest (Kissling and Schlunegger, 2018). This orogeny resulted in the construction of an ultimately bivergent orogen with the Periadriatic Lineament separating the Northern Alps from the Southern Alps (Schmid et al., 1989). The core of the north- and northwest-vergent Northern Alps is characterized by pervasive Alpine ductile deformation and metamorphism of the basement and associated cover units (Schmid et al., 2004). The south-vergent Southern Alps generally experienced thick- and thin-skinned deformation (Laubscher, 1983) with limited Alpine metamorphic overprinting.

The litho-tectonic units of the Northern Alps have been categorized into three broad nappe systems based on their paleogeographic position in Mesozoic times (Fig. 1; Schmid et al., 2004; Spiegel et al., 2004). The Helvetic units along the northern margin of the orogen form a stack of thrust sheets that consist of Mesozoic limestones and marls. These sediments accumulated on the stretched (Helvetic units) and distal rifted (Ultrahelvetic units) European continental margin during the Mesozoic phase of rifting and spreading (Schmid et al., 1996; Schmid et al., 2004). The basal thrust of the Helvetic nappes, referred to as the basal Alpine thrust (Fig. 1), was folded in response to basement-involved shortening within the European plate at $\sim 20 \mathrm{Ma}$, resulting in the uplift of the external massifs (Herwegh et al., 2017), ex- 


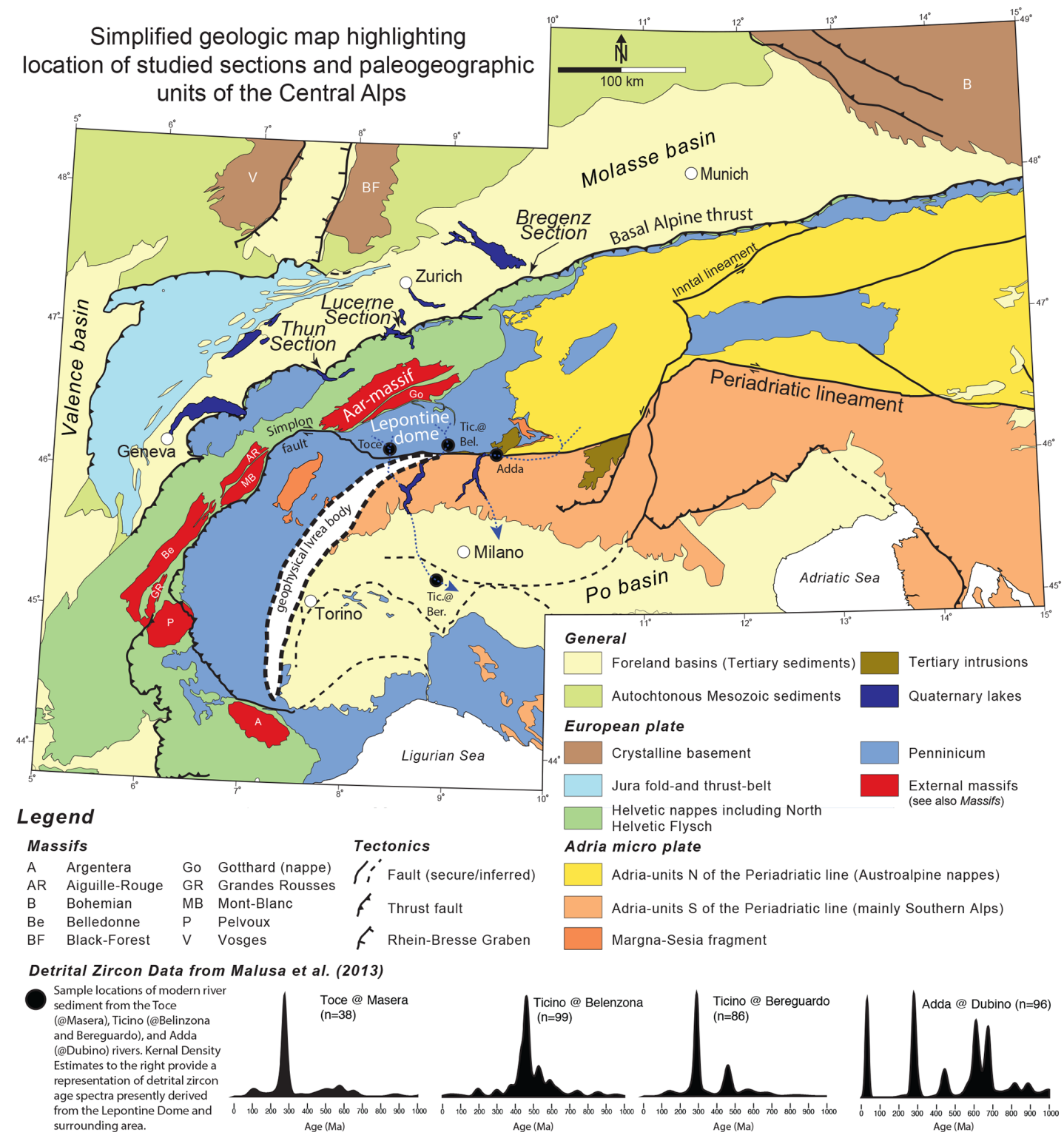

Figure 1. Geologic map of the Central Alps and Swiss Molasse Basin highlighting geologic features and paleogeographic units discussed in the text (map is adapted from Garefalakis and Schlunegger, 2019, and based on Froitzheim et al., 1996, Schmid et al., 2004, Handy et al., 2010, and Kissling and Schlunegger, 2018). Locations are shown for the Lucerne Section, Thun Section, and Bregenz Section, which are highlighted in Fig. 3a, b, and c, respectively. Kernel density estimates (KDEs; bandwidth set to 10) of detrital zircon U-Pb age data from modern river samples (Malusà et al., 2013) represent potential age spectra of currently exposed units within and surrounding the Lepontine dome.

posing Variscan amphibolites and metagranites dated by U$\mathrm{Pb}$ geochronology to between 290 and $330 \mathrm{Ma}$ (Schaltegger et al., 2003; von Raumer et al., 2009). The Penninic units represent the oceanic domains of the Piemont-Liguria and Valais basins, separated by the Briançonnais or Iberian microcontinent (Schmid et al., 1996). The Austroalpine units, both basement and sedimentary cover, formed the northern margin of the Adriatic plate (Pfiffner et al., 2002; Schmid et al., 2004; Handy et al., 2010). While there are few Austroalpine units preserved in the Western and Central Alps, where the exposed rocks belong mainly to the Helvetic and Penninic units, the Austroalpine rocks dominate the Eastern Alps forming an orogenic lid, with Penninic and Helvetic units only exposed in tectonic windows (Fig. 1; Schmid et al., 2004). The Lepontine dome forms the crystalline core of the Penninic nappes and mainly exposes moderate- to high-grade Variscan ortho- and paragneisses separated by Mesozoic metasedimentary slivers (Spicher, 1980). Along the western margin, the dome is bordered by the extensional Simplon shear zone and detachment fault (Manck- 
telow, 1985; Schmid et al., 1996), accommodating tectonic exhumation since $\sim 30 \mathrm{Ma}$ (Gebauer, 1999). Detrital thermochronometric data collected both north and south of the Central Alps have been used to suggest that exhumation rates occurred at a relatively steady state after $15 \mathrm{Ma}$ (Bernet et al., 2001, 2009). However, this notion has been disputed by Carrapa (2010) arguing for exhumation variations directly reflecting the dynamic evolution of the orogenic wedge. Overall rates of synorogenic unroofing of the Lepontine dome appears to have peaked between 20 and $15 \mathrm{Ma}$ (Grasemann and Mancktelow, 1993; Carrapa, 2009; Boston et al., 2017) on the basis of cooling ages, although rates potentially began to increase prior to $20 \mathrm{Ma}$ as suggested by Schlunegger and Willett (1999), considering a thermal lag time after the onset of faulting.

\subsection{Pre-Alpine tectonic evolution}

Since the Neoproterozoic a number of pre-Alpine orogenies have contributed to the growth and reworking of the continental crust of the European, Iberian, and Adriatic plates that now make up the Alpine Orogen (von Raumer, 1998; Schaltegger and Gebauer, 1999; Schaltegger et al., 2003). As it is important to understand these precursor orogenic events recorded by the detrital zircon data, these orogenic cycles are discussed below from oldest to youngest.

\subsubsection{Pan-African and Cadomian orogenies}

The Pan-African orogenic cycle refers to a series of protracted late Neoproterozoic orogenic events that resulted in the amalgamation of Gondwana (e.g., Kröner and Stern, 2004). This includes the East African orogen, prominently exposed in the Arabian-Nubian Shield, that resulted in the accretion of predominantly juvenile late Neoproterozoic magmatic crust (750-600 Ma) and the ultimate suturing of East and West Gondwana. These juvenile magmatic rocks and older basement of the Saharan Metacraton formed the late Neoproterozoic crust along the northern margin of Gondwana.

This NE African margin of Gondwana was subsequently overprinted by the Cadomian orogeny. It has been interpreted as an Andean-style Peri-Gondwanan belt that resulted in the accretion of island arc and continental margin strata along the Gondwanan continental margin from late Neoproterozoic to Cambrian times (von Raumer et al., 2002; Kröner and Stern, 2004). In general, the age range of this orogenic cycle is overall younger than the Pan-African and broadly spanning 650 to $550 \mathrm{Ma}$, although some consider the orogenic cycle to encompass a greater time span of 700-480 Ma (D'Lemos et al., 1990). In the present Alpine Orogen, recycled detritus related to the Pan-African and Cadomian orogenies is preserved in the basement units of the Gotthard nappe, Habach complex, and Austroalpine Silvretta nappe (Müller et al., 1996), as well as in the Mesozoic and Cenozoic strata of the Schlieren Flysch (Bütler et al., 2011). Pan-African and Cadomian zircon $\mathrm{U}-\mathrm{Pb}$ crystallization ages, preserved in both the sedimentary and basement units, range from 650 to $600 \mathrm{Ma}$ (Neubauer, 2002). While Cadomian magmatism lasted until at least $520 \mathrm{Ma}$ (Neubauer, 2002), the main phase is roughly synchronous or slightly younger than the PanAfrican orogeny (Kröner and Stern, 2004). Hence, early Ediacaran detrital zircons are difficult to definitively link to either Pan-African or Cadomian sources, especially as they could be recycled from Paleozoic strata (e.g., Hart et al., 2016; Stephan et al., 2019a).

\subsubsection{Caledonian-Sardic Orogeny}

Evidence for Ordovician Caledonian-aged tectonism and magmatism are preserved in all of the major Alpine tectonic units (von Raumer, 1998; Engi et al., 2004). The Aar Massif and Gotthard nappe of central Switzerland (Schaltegger et al., 2003), associated with the European continental lithosphere, as well the Austroalpine Silvretta nappe contain Caledonian-aged granitoids (Schaltegger and Gebauer, 1999) and Precambrian recycled zircon ages (Gebauer et al., 1988). In addition, sedimentary units, such as the Ultrahelvetic Flysch, also contain Ordovician detrital zircon grains (Bütler et al., 2011). Although felsic and mafic magmatism and high-pressure metamorphism associated with this Caledonian-aged orogenic cycle (480-450 Ma) are identified in the Alpine basement units, the exact geodynamic setting remains unclear (Schaltegger et al., 2003). While the debate about subduction polarity persists, it is clear that crustal fragments were accreted to the Gondwanan margin during the Caledonian Orogeny (Schaltegger et al., 2003). While these events have been called Caledonian, they are unlikely associated with the Caledonian (Scandian or Taconic) Orogeny. This has been previously recognized and magmatism has been suggested to be associated with OrdovicianDevonian extensional tectonism along the Peri-Gondwanan margin of Arabia and NE Africa. Zurbriggen (2017) referred to these events as the Cenerian Orogen, while other studies have referred to it as Sardic (see Stephan et al., 2019b). In many ways, however, this magmatism is a continuation of older Cadomian syn-convergent magmatism along the PeriGondwana margin. In order to avoid confusion here, and for simplicity, we will adhere to referring to this as Caledonianaged rather than Sardic or Cenerian.

\subsubsection{Variscan Orogeny}

While the Pan-Africanor Cadomian and Caledonian-aged orogenies left limited imprints on the Alpine basement, the Variscan orogeny impacted large portions of pre-Alpine crustal basement units in a major way (von Raumer, 1998; von Raumer et al., 2002). The Variscan orogen was the result of the collision between the Gondwana and LaurussiaAvalonia continental plates, which resulted in the formation 
of the super-continent Pangaea (Franke, 2006). The closure of the Paleo-Tethys and the Rheno-Hercynian oceans, leading to the formation of Pangaea, started at $\sim 400 \mathrm{Ma}$ and ended in a continent-continent collision at $300 \mathrm{Ma}$. It was characterized by voluminous syn- and post-orogenic plutonic magmatism (Franke, 2006; von Raumer et al., 2009 and references therein). The final stage of post-orogenic Variscan magmatism lasted until $\sim 250 \mathrm{Ma}$ (Finger et al., 1997). The Aar Massif and Gotthard nappe, located south of the central Swiss study location (Fig. 1), contain voluminous Variscan U-Pb plutonic rocks (Schaltegger, 1994). While the external massifs of the northern part of Central Alps also contain abundant Variscan crustal material (von Raumer et al., 2003; Engi et al., 2004; Franke, 2006), they were not exposed to erosion until $\sim 14 \mathrm{Ma}$ (Stutenbecker et al., 2019).

\subsubsection{Alpine Orogeny}

The collision history between the European and Adriatic continental plates commenced in the Late Cretaceous with the closure of portions of the Alpine Tethys and subduction of the European plate beneath the Adriatic continental plate (Schmid et al., 1996). This Eo-Alpine subduction resulted in blueschist and eclogite facies metamorphism (Ring, 1992; Engi et al., 1995; Rubatto et al., 2011) of rocks that are preserved in slivers between the Penninic nappe stack of the Lepontine dome (e.g., Cima Lunga nappe; Schmid et al., 1996). The main Alpine continent-continent collision started at $\sim 33 \mathrm{Ma}$, when the European continental lithosphere started to enter the subduction channel (Schmid et al., 1996). The buoyancy differences between the oceanic lithosphere and the buoyant continental lithosphere potentially resulted in oceanic slab break-off and at a resulting magmatic flare-up at $\sim 32 \mathrm{Ma}$ (Davis and von Blanckenburg, 1995; Schmid et al., 1996). The subsequent advection of heat resulted in a Barrovian-type high-grade metamorphism in the area of the Lepontine dome (Frey et al., 1980; Hurford, 1986; Kissling and Schlunegger, 2018).

The Helvetic thrust nappes, overthrust by Penninic and Austroalpine nappes prior to the time of slab break-off, experienced greenschist and prehnite-pumpellyite metamorphism between 35 and $30 \mathrm{Ma}$ (Frey et al., 1980; Hunziker et al., 1992). Emplacement and thrusting of the Helvetic nappes along the basal Alpine thrust on the proximal European margin (Fig. 1) occurred between 25 and $20 \mathrm{Ma}$ and resulted in a greenschist overprint of the basement in the external massifs (Niggli and Niggli, 1965; Frey et al., 1980; Rahn et al., 1994). A late-stage phase of basement-involved duplexing resulted in the rise of the external massifs and the final shape of the Central Alps (Herwegh et al., 2017; Mair et al., 2018; Herwegh et al., 2019).

\section{Molasse Basin: architecture, stratigraphy, and provenance}

The Molasse Basin extends $\sim 600 \mathrm{~km}$ from Lake Geneva to the Bohemian Massif (Kuhleman and Kempf, 2002; Fig. 1). The Swiss part of the Molasse Basin, a subsection of this foreland trough, is located between Lake Geneva and Lake Constance and is the focus of this study. It is flanked in the north by the Jura Mountains and in the south by the Central Alps. The basin is commonly divided into the Plateau Molasse, the undeformed central basin, and the Subalpine Molasse, the deformed basin adjacent to the Central Alps. The Cenozoic strata of the flexural Swiss Molasse Basin have been divided into five lithostratigraphic units that are (oldest to youngest) (Sinclair and Allen, 1992): the North Helvetic Flysch (NHF), the Lower Marine Molasse (LMM), the Lower Freshwater Molasse (LFM), the Upper Marine Molasse (UMM), and the Upper Freshwater Molasse (UFM) (Fig. 2; Sinclair and Allen, 1992). Overall, they record two large-scale shallowing- and coarsening-upward sequences that formed in response to Alpine tectonic processes and changes in sediment supply rates (Fig. 2; Matter et al., 1980; Pfiffner, 1986; Sinclair and Allen, 1992; Sinclair et al., 1997; Kuhlemann and Kempf, 2002; Garefalakis and Schlunegger, 2018).

\subsection{North Helvetic Flysch}

The earliest foreland basin deposits comprise the NHF with initial turbidite deposition starting in the middle to late Eocene (Allen et al., 1991). During that time, clastic deepwater sediments accumulated along the attenuated European continental margin (Crampton and Allen, 1995). The NHF was sourced from the approaching earliest Alpine thrust sheets (Allen et al., 1991). In central Switzerland, the NHF includes sandstone, shale, and some volcanic detritus derived from the volcanic arc situated on the Adriatic plate at that time (Lu et al., 2018; Reichenwallner, 2019). The initial deep-marine, turbiditic clastic deposits exhibit orogenparallel transport from the west (Sinclair and Allen, 1992). Currently, NHF strata in the region are highly deformed and tectonically located below the Helvetic thrust nappes (Pfiffner, 1986).

\subsection{Lower Marine Molasse}

After deep-marine deposition of the NHF, sedimentation associated with the LMM continued in an underfilled flexural foredeep (Sinclair et al., 1997). From 34 to $30 \mathrm{Ma}$ (Pfiffner et al., 2002 and references therein) deposition of the LMM progressively transitioned from deep-marine turbidites to tabular and cross-bedded sandstones with symmetrical wave ripples (Matter et al., 1980; Diem, 1986) recording a storm- and wave-dominated shallow-marine environment (Diem, 1986; Schlunegger et al., 2007). The LMM strata record paleocur- 


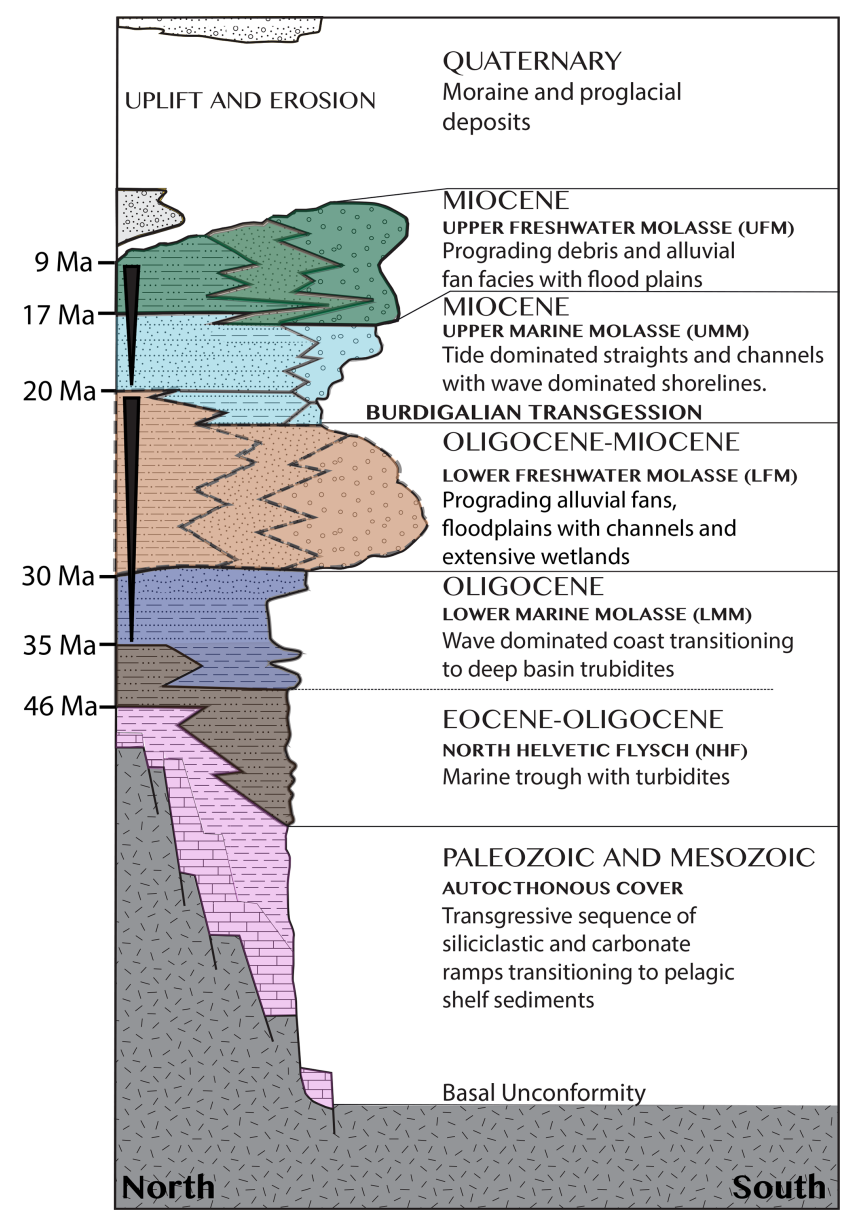

Figure 2. Generalized stratigraphy of the Molasse Basin. Modified from Keller (2000). Black arrows indicate the two large-scale shallowing- and coarsening-upward sequences discussed in detail in Sect. 3.

rent directions that were mostly perpendicular to the orogenic front with a NE-directed tendency (Diem, 1986; Kempf et al., 1999). Sandstone provenance of the LMM suggests mainly derivation from recycled Penninic sedimentary rocks situated along the Alpine front at the time (Gasser, 1968; Matter et al. 1980; Spiegel et al. 2002). Outcrops of the LMM are restricted to the deformed wedge of the Subalpine Molasse.

Increased sediment supply in response to rapid erosion of the emerging Alpine orogenic wedge resulted in overfilling of the Swiss Molasse Basin, signaling the shift from the LMM to the fluvial and alluvial deposits of the LFM (Sinclair and Allen, 1992; Sinclair et al., 1997; Kuhlemann and Kempf, 2002; Schlunegger and Castelltort, 2016; Garefalakis and Schlunegger, 2018). The transition to the LFM was also characterized by the first-appearance of Alpine-derived conglomerates at $\sim 30 \mathrm{Ma}$ in central Switzerland (Schlunegger et al., 1997a; Kempf et al., 1999; Kuhlemann and Kempf, 2002).

\subsection{Lower Freshwater Molasse}

Within the Swiss Molasse Basin, the deposition of the LFM occurred between $\sim 30$ and $20 \mathrm{Ma}$ (Kempf et al., 1999). A regional hiatus separated these older pre-25 Ma (LFM I) from the younger post-24 Ma fluvial deposits (LFM II) (Schlunegger et al., 1997a). In central Switzerland a $\sim 4 \mathrm{~km}$ wedge of the LFM is preserved (Stürm, 1973), with the thickest exposed LFM suites occurring in the Subalpine Molasse belt adjacent to the thrust front, such as the Rigi and Höhronen conglomeratic megafans (and others) (Schlunegger et al., 1997b, c). During the $\sim 25-24$ Ma hiatus, deposition switched from the Rigi to the Höhronen fan (Schlunegger et al., 1997b, c). Alluvial fan deposition transitioned to channel conglomerates and sandstones away from the thrust front (Büchi and Schlanke, 1977; Platt and Keller, 1992). Limestone, metamorphic, igneous, and ophiolitic clasts derived from the Penninic and Austroalpine units dominated LFM alluvial fan conglomerates (e.g., von Eynatten et al., 1999; Spiegel et al., 2004). Flysch sandstone clasts recycled in the LFM also indicate erosion of older Penninic flysch units (Gasser, 1968). A distinct change in clast LFM composition occurred at $\sim 24 \mathrm{Ma}$ and marked the shift from LFM I to LFM II. This change was characterized by the switch from $>80 \%$ sedimentary clasts in the Rigi fan prior to $25 \mathrm{Ma}$ (Stürm, 1973) to $>50 \%-60 \%$ crystalline granitic clasts in the Höhronen fan thereafter (Schlunegger et al., 1997a; von Eynatten and Wijbrans, 2003). After $\sim 21 \mathrm{Ma}$, rapid, largemagnitude tectonic exhumation of the Lepontine dome, in response to syn-orogenic extensions (Mancktelow and Grasemann, 1997), led to widespread exposure of the Penninic core complex as evidenced by Alpine-aged detrital mica ${ }^{40} \mathrm{Ar} /{ }^{39} \mathrm{Ar}$ ages in the Molasse Basin (von Eynatten et al., 1999) and cooling patterns recorded by zircon fission track ages in conglomerate clasts (Spiegel et al., 2000, 2001). At $\sim 21 \mathrm{Ma}$, a significant shift in provenance marked the transition from LFM IIa (prior to $21 \mathrm{Ma}$ ) to LFM IIb (21 to $20 \mathrm{Ma}$ ) and was signaled by a change in sandstone heavymineral compositions, as epidote sources within the Penninic nappes beneath the detachment faults (Spiegel et al., 2002) started to dominate the heavy-mineral suite by more than $90 \%$ (Schlanke, 1974; Kempf et al., 1999). This shift was also accompanied by a trend toward more fine-grained sedimentation (Schlunegger et al., 1997a). However, implications of this shift in provenance have been non-conclusive, as Renz (1937), Füchtbauer (1964), and Dietrich (1969) suggested that the epidote minerals were derived from Penninic ophiolites, while Füchtbauer (1964) claimed sourcing from crystalline and greenschist units in the Austroalpine nappes. However, based on $\mathrm{Sr}$ and $\mathrm{Nd}$ isotopic data from detrital epidote, Spiegel et al. (2002) deduced an ultramafic source for the detrital epidote in all fan systems. They envisioned that in early Miocene times, ophiolitic rocks from the very top of the Penninic nappe stack became unroofed by detachment faults and exposed over large areas of the Central Alps. 


\subsection{Upper Marine Molasse}

Continental deposition of the LFM was followed by a shift to marine sedimentation of the UMM in the Swiss Foreland Basin (Keller, 1989). This has been interpreted as a change back to underfilled conditions. A return towards an underfilled basin started already during LFM times at $\sim 21 \mathrm{Ma}$ and was characterized by a continuous reduction in sediment supply rates (Kuhlemann, 2000; Spiegel et al., 2004; Willett, 2010). Marine conditions began in the eastern Molasse Basin and propagated westward (Strunck and Matter, 2002; Garefalakis and Schlunegger, 2019). These related effects appear to have been amplified by a tectonically controlled widening of the basin (Garefalakis and Schlunegger, 2019). This change from overfilled non-marine to under-filled marine conditions is referred to as the Burdigalian Transgression (Fig. 2; Sinclair et al., 1991). However, the debate continues whether the cause of the Burdigalian Transgression is due to (i) an increase in sea level outpacing sedimentation (Jin et al., 1995; Zweigel et al., 1998), (ii) an increase in tectonic loading through thrusting of the external massifs (Sinclair et al., 1991), or (iii) an increase in slab pull causing more flexure of the European plate paired with a reduction in sediment supply and a rising eustatic sea level (Garefalakis and Schlunegger, 2019).

The Burdigalian Transgression resulted in the deposition of wave and tide-dominated sandstones in a shallow marine environment (Allen et al., 1985; Homewood et al., 1986; Keller, 1989; Jost et al., 2016; Garefalakis and Schlunegger, 2019). At the thrust front these shallow-marine sandstones interfinger with fan delta deposits. Shallow-marine deposition lasted until 17 Ma (Schlunegger et al., 1997c). Heavymineral data (Allen et al., 1985) and clast petrography analysis (Matter, 1964), in conjunction with measurements of clast orientations in conglomerates and cross beds in sandstones (Allen et al., 1985; Garefalakis and Schlunegger, 2019), reveal that the UMM of Switzerland was a semi-closed basin. Detritus sourced from the Central Alps was deposited adjacent to the fan deltas and reworked by waves and tidal currents.

\subsection{Upper Freshwater Molasse}

The UFM consists of non-marine conglomerates and sandstones deposited in prograding alluvial fans and fluvial floodplains (Keller, 2000). The thickest section of the preserved UFM $(\sim 1500 \mathrm{~m})$ is situated to the west of Lucerne (Matter, 1964). The geochemistry of detrital garnet in the UFM records the first signal of erosion of the external massifs by $\sim 14 \mathrm{Ma}$ at the latest (Stutenbecker et al., 2019).

Deposition of the UFM in central Switzerland is only recorded until $\sim 13 \mathrm{Ma}$ (Kempf and Matter, 1999) as younger strata were eroded from the region (e.g., Burkhard and Sommaruga, 1998; Cederbom et al., 2004; Cederbom et al., 2011). Vitrinite reflectance and apatite fission track borehole data from the Molasse Basin suggest that up to $700 \mathrm{~m}$ of UFM strata were removed by erosion (Schegg et al., 1999; Cederbom et al., 2004, 2011). Erosion of the basin fill started in the late Miocene to Pliocene (Mazurek et al., 2006; Cederbom et al., 2011) after active thrusting propagated to the Jura Mountains, and the Molasse Basin essentially became a piggy-back basin (Burkhard and Sommaruga, 1998; Pfiffner et al., 2002) or alternatively a negative alpha basin (Willett and Schlunegger, 2011).

\section{Sampling strategy and methodology}

\subsection{Sampling strategy}

Samples were collected along the southern portion of the basin within the Plateau Molasse, the Subalpine Molasse, and the North Helvetic Flysch. Three sections were sampled: The Lucerne Section in central Switzerland, the Thun Section in west-central Switzerland, and the Bregenz Section in westernmost Austria (Figs. 1 and 3; Table 1). Sampling in the Lucerne Section was accomplished to cover the full range in depositional ages from the North Helvetic Flysch to the Upper Freshwater Molasse, spanning between 34 and 13.5 Ma with less than a $2-5 \mathrm{Myr}$ time resolution. For the $\sim 22.5$ to $19 \mathrm{Ma}$ time interval within the Lucerne Section, our highdensity strategy sampled at a temporal resolution of $<1$ Ma. Sample sites in the Bregenz Section covered the major lithostratigraphic groups of the Molasse deposits at a lower resolution, while samples from the Thun Section comprised only the LFM and terrestrial equivalents of the UMM deposits for an along-strike comparison. All separated samples contained detrital zircon and were used for U-Pb age dating. Stratigraphic age assignments for the samples for the Lucerne Section were based on the chronological framework from Schlunegger et al. (1997a), established in the Lucerne area through detailed magneto- and biostratigraphy (e.g., Weggis, Rigi, and Höhrone conglomerates; LFM I and LFM IIa/IIb units). Following Garefalakis and Schlunegger (2019), we updated the original correlation of the magnetopolarity stratigraphies (Schlunegger et al., 1997a), thereby considering the most recent revision of the magnetopolarity timescale by Lourens et al. (2004). Ages were projected into the Lucerne Section using published maps and balanced cross section restorations as basis (Schlunegger et al., 1997a). Chronostratigraphic age constraints for the UMM sandstones were taken from Keller (1989), Jost et al. (2016), and Garefalakis and Schlunegger (2019). Precise ages for the UFM units are not available, and they could comprise the entire range between $17 \mathrm{Ma}$ (base of UFM) and $\sim 13 \mathrm{Ma}$ (youngest LFM deposits in Switzerland; Kempf and Matter, 1999). The chronological framework for the Molasse units for the Thun Section is based on litho- and chronostratigraphic work by Schlunegger et al. (1993, 1996). There, OA13- samples were collected along the magnetostratigraphic section of 
Schlunegger et al. (1996) with an age precision of $\sim 0.5 \mathrm{Ma}$. Sample 10SMB07 was collected from a conglomerate unit, mapped (Beck and Rutsch, 1949) as a terrestrial equivalent of the UMM (Burdigalian), although the depositional age could also correspond to the UFM (Langhian), as indicated by litho- and seismo-stratigraphic and heavy-mineral data from a deep well (Schlunegger et al., 1993). Site 10SMB06 comprises a suite of conglomerates with quartzite clasts their first appearance was dated to $\sim 25 \mathrm{Ma}$ in the adjacent thrust sheet to the south (Schlunegger et al., 1996). While deposition of quartzite clasts, however, continues well into the UFM (Matter, 1964), the quartzite conglomerates in the Thun Section (10SMB06) directly overly sandstones of the LFM II as a tectonic interpretation of a seismic section has revealed (Schlunegger et al., 1993). Therefore, we tentatively assigned an LFM II age to the 10SMB06 sample site. Finally, sampling and stratigraphic age assignments for samples from the Bregenz Section were guided by the geological map of Oberhauser (1994) and by additional chronologic (Kempf et al., 1999) and stratigraphic work (Schaad et al., 1992). We considered an uncertainty of $\pm 2 \mathrm{Ma}$ to the age assignment for the Bregenz Section samples.

\subsection{Zircon U-Pb laser ablation-inductively coupled plasma-mass spectrometry (LA-ICP-MS) methodology}

The bulk of the detrital zircon samples were analyzed at the UTChron geochronology facility in the Department of Geological Sciences at the University of Texas at Austin and a smaller subset at the at the Isotope Geochemistry Lab (IGL) in the Department of Geology at the University of Kansas, using identical instrumentation and very similar analytical procedures but different data reduction software (Table 1). All samples underwent conventional heavy-mineral separation, including crushing, grinding, water tabling, magnetic, and heavy liquid separations, but no sieving at any point (analyzed grains range in size from 30 to $350 \mu \mathrm{m}$ ). Separate zircon grains were mounted on double-sided tape (tape mount) on a $1^{\prime \prime}$ acrylic or epoxy disc without polishing. For all samples 120-140 grains were randomly selected for LA-ICP-MS analysis to avoid biases and to capture all major age components (> 5\%) (Vermeesch, 2004). All grains were depth-profiled using a Photon Machines Analyte G2 ATLex 300si ArF $193 \mathrm{~nm}$ excimer laser combined with a Thermo Scientific ${ }^{\mathrm{TM}}$ Element $2^{\mathrm{TM}}$ single-collector, magneticsector ICP-MS, following analytical protocols of Marsh and Stockli (2015). Thirty seconds of background was measured followed by 10 pre-ablation "cleaning" shots, then $15 \mathrm{~s}$ of washout to measure background, prior to $30 \mathrm{~s}$ of sample analysis. Each grain was ablated for $30 \mathrm{~s}$ using a $30 \mu \mathrm{m}$ spot with a fluence of $\sim 4 \mathrm{~J} \mathrm{~cm}^{-2}$, resulting in $\sim 20 \mu \mathrm{m}$ deep ablation pits. For $\mathrm{U}-\mathrm{Pb}$ geochronologic analyses of detrital zircon the masses ${ }^{202} \mathrm{Hg},{ }^{204} \mathrm{~Pb},{ }^{206} \mathrm{~Pb},{ }^{207} \mathrm{~Pb},{ }^{208} \mathrm{~Pb},{ }^{232} \mathrm{Th},{ }^{235} \mathrm{U}$, and ${ }^{238} \mathrm{U}$ were measured.
GJ1 was used as primary zircon standard $\left({ }^{206} \mathrm{~Pb} /{ }^{238} \mathrm{U}\right.$ $601.7 \pm 1.3 \mathrm{Ma},{ }^{207} \mathrm{~Pb} /{ }^{206} \mathrm{~Pb} 607 \pm 4 \mathrm{Ma}$; Jackson et al., 2004) and interspersed every three to four unknown analyses for elemental and depth-dependent fractionation. Plesovice (337.1 $\pm 0.4 \mathrm{Ma}$; Slama et al., 2008) was used as a secondary standard for quality control, yielding ${ }^{206} \mathrm{~Pb} /{ }^{238} \mathrm{U}$ ages during this study of $338 \pm 6 \mathrm{Ma}$, which is in agreement with the published age. No common- $\mathrm{Pb}$ correction was applied. At UTChron, data reduction was performed using the IgorPro-based iolite 3.4 software (Paton et al., 2010) with the Visual Age data reduction scheme (Petrus and Kamber, 2012), while at the University of Kansas (KU)'s IGL, U$\mathrm{Pb}$ data were reduced using PepiAGE (Dunkl et al., 2009) or iolite employing an Andersen (2002) correction method and decay constants from Steiger and Jäger (1977). The Andersen (2002) correction method iteratively calculates the ${ }^{208} \mathrm{~Pb} /{ }^{232} \mathrm{Th},{ }^{207} \mathrm{~Pb} /{ }^{235} \mathrm{U}$, and ${ }^{206} \mathrm{~Pb} /{ }^{238} \mathrm{U}$ ages to correct for common- $\mathrm{Pb}$ where ${ }^{204} \mathrm{~Pb}$ cannot be accurately measured. Sample 09SFB11 was reduced using PepiAGE and for this reason $\mathrm{U}$ parts per million and the $\mathrm{U} / \mathrm{Th}$ ratio were not calculated.

All uncertainties are quoted at $2 \sigma$, and age uncertainty of reference materials are not propagated. For ages younger than $900 \mathrm{Ma},{ }^{206} \mathrm{~Pb} /{ }^{238} \mathrm{U}$ ages are reported and grains were eliminated from text and figures if there was more than $10 \%$ discordance between the ${ }^{206} \mathrm{~Pb} /{ }^{238} \mathrm{U}$ age and the ${ }^{207} \mathrm{~Pb} /{ }^{235} \mathrm{U}$ age or the ${ }^{206} \mathrm{~Pb} /{ }^{238} \mathrm{U}$ age had more than $10 \% 2 \sigma$ absolute error. For ages older than $900 \mathrm{Ma},{ }^{207} \mathrm{~Pb} /{ }^{206} \mathrm{~Pb}$ ages are reported and grains were eliminated from text and figures if there was more than $20 \%$ discordance between ${ }^{206} \mathrm{~Pb} /{ }^{238} \mathrm{U}$ age and ${ }^{207} \mathrm{~Pb} /{ }^{206} \mathrm{~Pb}$ age. Analytical data were visually inspected for common- $\mathrm{Pb}$, inheritance, or $\mathrm{Pb}$ loss using the VizualAge live concordia function (Petrus and Kamber, 2012). Laser ablation ICP-MS depth profiling allows for the definition of more than one age from a single grain; hence ages in Table S1 in the Supplement are labeled either single age, rim, or core. Commonly a single concordant age was obtained for each zircon; however, if more than one concordant age was defined then both analyses were included in the data reporting.

\subsection{Laser-ablation-split-stream analyses of detrital zircon}

In an attempt to glean additional provenance constraints from Molasse samples, we also combined $\mathrm{U}-\mathrm{Pb}$ with trace element (TE) and rare-earth element (REE) analyses on the same grain for select samples via laser-ablation-splitsteam (LASS) U-Pb analysis at the University of Texas at Austin (Marsh and Stockli, 2015). Combined U-Pb isotopic and TE/REE data can help improve provenance resolution on the basis of petrogenic affiliations of individual grains (Kylander-Clark et al., 2013). For LASS analysis, ablated aerosols were divided between two identical Thermo Scientific $^{\mathrm{TM}}$ Element $2^{\mathrm{TM}}$ single-collector, magnetic-sector ICP- 


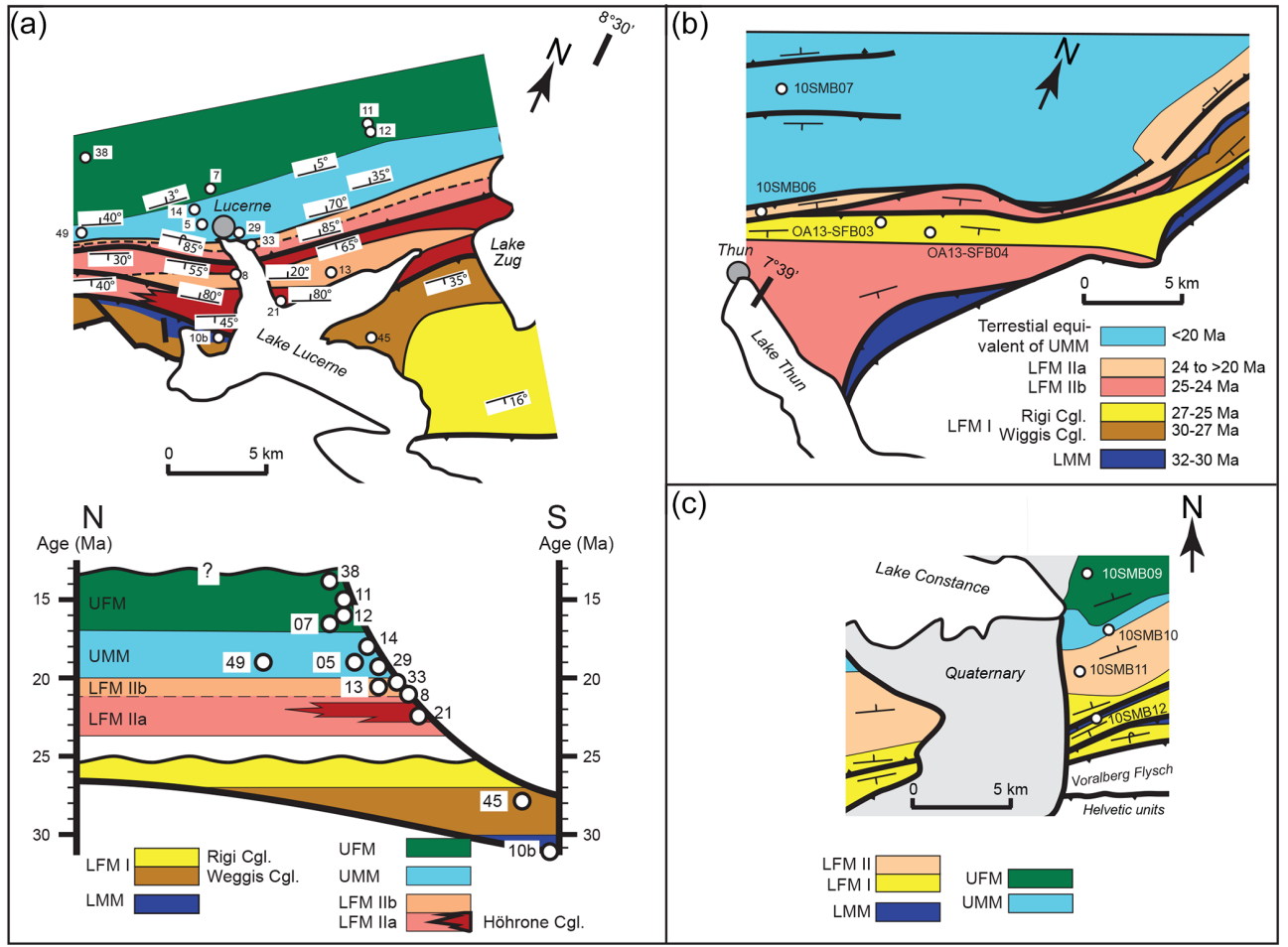

Figure 3. Stratigraphic units and sample locations of the three sampled sections. (a) Lucerne Section: geologic map and cross section modified from Schlunegger et al. (1997a). In both the map and the simplified cross section, sample numbers are only the last two digits of the sample numbers from Table 1. (b) Thun Section: geologic map modified from Schlunegger et al. (1993, 1996). (c) Bregenz Section: geologic map simplified from Oberhauser (1994), Kempf et al. (1999), and Schaad et al. (1992).

MS instruments and analyzed for ${ }^{29} \mathrm{Si},{ }^{49} \mathrm{Ti},{ }^{89} \mathrm{Y},{ }^{137} \mathrm{Ba}$, ${ }^{139} \mathrm{La},{ }^{140} \mathrm{Ce},{ }^{141} \mathrm{Pr},{ }^{146} \mathrm{Nd},{ }^{147} \mathrm{Sm},{ }^{153} \mathrm{Eu},{ }^{157} \mathrm{Gd},{ }^{159} \mathrm{~Tb}$, ${ }^{163} \mathrm{Dy},{ }^{165} \mathrm{Ho},{ }^{166} \mathrm{Er},{ }^{169} \mathrm{Tm},{ }^{172} \mathrm{Yb},{ }^{175} \mathrm{Lu},{ }^{178} \mathrm{Hf},{ }^{181} \mathrm{Ta}$, ${ }^{232} \mathrm{Th}$, and ${ }^{238} \mathrm{U}$. Data generated from the TE and REE analyses were reduced using the "Trace_Elements_IS" data reduction scheme from iolite (Paton et al., 2011), using ${ }^{29} \mathrm{Si}$ as an internal standard indexed at $15.3216 \mathrm{wt} \%{ }^{29} \mathrm{Si}$. NIST612 was used as the primary reference material and GJ1 and Pak1 as secondary standards to verify data accuracy.

\subsection{Zircon elemental analysis}

While studies (e.g., Hoskin and Ireland, 2000; Belousova et al., 2002) have shown that zircon REE patterns in general do not show systematic diagnostic variations as a function of different continental crustal rock types (von Eynatten and Dunkl, 2012), it has been shown that TE and REE can be used to differentiate between igneous zircon from continental (e.g., arc), oceanic, and island arc tectono-magmatic environments (Grimes et al., 2015). Furthermore, trace elements and REEs can be used to fingerprint zircon with mantle affinity (i.e., kimberlites and carbonatites; Hoskin and Ireland, 2000), hydrothermal zircon (Hoskin, 2005), or zircon that grew or recrystallized under high-grade metamorphic conditions (Rubatto, 2002). Furthermore, Ce and Eu anomalies in zircons have been used as proxies for magmatic oxidation states (Trail et al., 2012; Zhong et al., 2019) and Ti in zircon as a crystallization thermometer (Watson et al., 2006). Detrital studies have utilized these techniques to identify characteristic zircon signatures from non-typical sources (e.g., Anfinson et al., 2016; Barber et al., 2019).

Chondrite-normalized REE zircon signatures were only considered for concordant $\mathrm{U}-\mathrm{Pb}$ ages as metamictization likely also affected REE and TE spectra. Zircon with anomalously elevated and flat light rare-earth element (LREE) (La$\mathrm{Gd}$ ) concentrations were excluded from figures and interpretations as these are likely due to mineral inclusions (i.e., apatite) or hydrothermal alteration (Bell et al., 2019).

\section{Detrital $\mathrm{U}-\mathrm{Pb}$ age groups and associated orogenic cycles}

In an attempt to simplify data presentation and data reporting, the detrital zircon $\mathrm{U}-\mathrm{Pb}$ ages were lumped into genetically related tectono-magmatic age groups that include the Variscan, Caledonian-Sardic, and Cadomian-PanAfrican orogenic cycles. In addition to these three preAlpine orogenic cycles we also considered the total number of Cenozoic (Alpine) ages, Mesozoic (Tethyan) ages, and pre-Cadomian ages. The following sections provide a brief description of the different delineated age groups. While 
Table 1. Sample information. Depositional age errors are based on the following references: Lucerne Section - Schlunegger et al. (1997a) with modifications using the most recent magnetopolarity timescale of Lourens et al. (2004); Thun Section - Schlunegger et al. (1993, 1996); Bregenz Section - Oberhauser (1994), Kempf et al. (1999), and Schaad et al. (1992). The " $\times$ " sign in the "U-Pb" and "Geochem" columns indicates that data are available for that sample. The final column indicates whether samples were analyzed at either the University of Kansas (KU) or the University of Texas at Austin (UT). Errors for depositional ages are discussed in further detail in Sect. 3. Corresponding methods are found in Sect. 4. SMB: Swiss Molasse Basin.

\begin{tabular}{|c|c|c|c|c|c|c|c|c|c|}
\hline Sample name & $\begin{array}{l}\text { Unit of } \\
\text { SMB }\end{array}$ & Latitude & Longitude & $\begin{array}{r}\text { Elevation } \\
(\mathrm{m})\end{array}$ & $\begin{array}{r}\text { Dep. age } \\
(\mathrm{Ma})\end{array}$ & $\pm \mathrm{Ma}$ & $\mathrm{U}-\mathrm{Pb}$ & Geochem & $\begin{array}{l}\text { Loc. of } \\
\text { analysis }\end{array}$ \\
\hline \multicolumn{10}{|l|}{ Thun, CH } \\
\hline OA13-SFB03 & LFM I & 46.789815 & 7.711673 & 740 & 27 & 0.5 & $x$ & & UT \\
\hline OA13-SFB04 & LFM I & 46.783249 & 7.730281 & 840 & 26 & 0.5 & $x$ & & UT \\
\hline 10SMB06 & LFM II & 46.77989 & 7.6556 & 689 & 23 & 2.5 & $x$ & & $\mathrm{KU}$ \\
\hline 10SMB07 & UFM & 46.81503 & 7.65013 & 689 & 18 & 3 & $x$ & & $\mathrm{KU}$ \\
\hline \multicolumn{10}{|l|}{ Lucerne, CH } \\
\hline 09-SFB-38 & UFM & 47.14054 & 8.19664 & 461 & 13.5 & 1 & $x$ & $x$ & UT \\
\hline 09-SFB-11 & UFM & 47.10245 & 8.35003 & 420 & 14 & 1 & $x$ & & KU \\
\hline 09-SFB-07 & UFM & 47.0569 & 8.24923 & 478 & 15.5 & 1 & $x$ & & UT \\
\hline 09-SFB-12 & UFM & 47.10245 & 8.35003 & 420 & 16 & 1 & $\times$ & & UT \\
\hline 09-SFB-14 & UMM & 47.06692 & 8.32032 & 476 & 17.5 & 1 & $x$ & $\times$ & UT \\
\hline 09-SFB-49 & UMM & 47.02051 & 8.2403 & 676 & 19 & 1 & $x$ & $\times$ & UT \\
\hline 09-SFB-29 & UMM & 47.06442 & 8.32369 & 498 & 19 & 1 & $x$ & & $\mathrm{KU}$ \\
\hline 09-SFB-05 & UMM & 47.05639 & 8.31036 & 398 & 20 & 1 & $x$ & & UT \\
\hline 09-SFB-33 & LFM IIb & 47.05681 & 8.34139 & 503 & 20.5 & 1 & $x$ & $\times$ & $\mathrm{UT}$ and $\mathrm{KU}$ \\
\hline 09-SFB-13 & LFM IIb & 47.0565 & 8.38408 & 547 & 20.5 & 1 & $x$ & & KU \\
\hline 09-SFB-08 & LFM IIb & 47.04211 & 8.32706 & 442 & 21 & 1 & $x$ & & UT \\
\hline 09-SFB-21 & LFM IIa & 47.03422 & 8.35363 & 436 & 22.5 & 1 & $x$ & $x$ & UT \\
\hline 09-SFB-45 & LFM I & 47.041 & 8.4614 & 1332 & 27 & 1 & $x$ & $\times$ & UT \\
\hline 09-SFB-10b & LMM & 47.00933 & 8.29391 & 615 & 32 & 1 & $x$ & & $\mathrm{KU}$ \\
\hline 09-SFB-43 & NHF & 46.87763 & 8.66345 & 496 & 35 & 3 & $x$ & $\times$ & \\
\hline 09-SFB-02 & NHF & 46.89991 & 8.6262 & 461 & 35 & 3 & $x$ & & $\mathrm{KU}$ \\
\hline \multicolumn{10}{|l|}{ Bregenz, AT } \\
\hline 10SMB09 & UFM & 47.53763 & 9.76789 & 609 & 15 & 2 & $x$ & & UT \\
\hline 10SMB10 & UMM & 47.50168 & 9.79451 & 622 & 19 & 2 & $x$ & & $\mathrm{UT}$ and $\mathrm{KU}$ \\
\hline 10SMB11 & LFM II & 47.48016 & 9.76906 & 442 & 22 & 2 & $\times$ & & UT \\
\hline 10SMB12 & LMM & 47.44407 & 9.78484 & 442 & 31 & 1 & $\times$ & & UT \\
\hline
\end{tabular}

there can be considerable debate regarding the exact duration of orogenic cycles (Dewey and Horsfield, 1970), grouping zircon $\mathrm{U}-\mathrm{Pb}$ ages according to their tectono-magmatic or orogenic affinity provides a convenient way to discuss potential detrital sources. The informal age ranges adopted in this study are Cenozoic (0 to 66 Ma), Mesozoic (66 to $252 \mathrm{Ma}$ ), late Variscan (252 to $300 \mathrm{Ma}$ ), early Variscan (300$370 \mathrm{Ma}$ ), Caledonian age (370 to $490 \mathrm{Ma}$ ), Cadomian-PanAfrican (490 to $710 \mathrm{Ma}$ ), and Pre-Cadomian (> 710 Ma). We simplified these age groups to represent a continuous series with no time gaps and to ensure no omission of ages and for simplicity of depicting ages using the DetritalPy software of Sharman et al. (2018b). Age group percentages reported in Sect. 6 are based on the number of ages within that age group compared to the number of ages from the whole sample, while percentages depicted in Figs. 4, 5, and
6 are based on the number of ages within that group compared to the number of ages depicted on the graph $(0-$ $1000 \mathrm{Ma})$. Abundant Variscan zircon U-Pb ages are split into two groups (late Variscan and early Variscan) to reflect differences between syn- and post-orogenic magmatism on the basis of discussion of Finger et al. (1997). Finger et al. (1997) noted five generalized genetic groups of granitoid production during the Variscan Orogeny: (1) Late Devonian to early Carboniferous I-type granitoids (370 to $340 \mathrm{Ma}$ ), (2) Early Carboniferous deformed S-type granitoids ( $340 \mathrm{Ma})$, (3) late-Visian-early-Namurian S-type and high-K I-type granitoids ( 340 to $310 \mathrm{Ma}$ ), (4) post-collisional I-type granitoids and tonalites (310-290 Ma), and (5) Late Carboniferous to Permian leucogranites (300-250 Ma). The general age ranges of the Caledonian-Sardic (370 to $490 \mathrm{Ma}$ ) and Cadomian-Pan-African (490 to $710 \mathrm{Ma}$ ) orogens are 


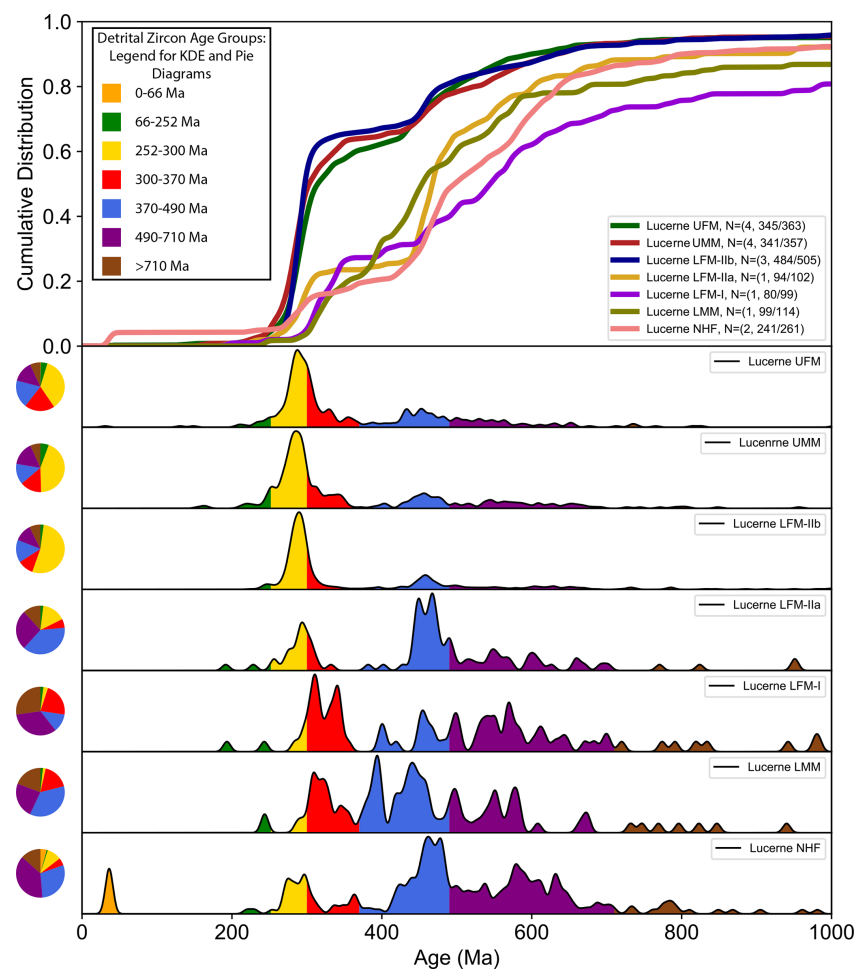

Figure 4. Detrital zircon $\mathrm{U}-\mathrm{Pb}$ age data from the Lucerne Section (locations of samples depicted in Fig. 3a) plotted as kernel density estimations (KDEs; Bandwidth set to 10), a cumulative distribution plot (CDP), and as pie diagrams. Colored bars in the KDE and colored wedges in the pie diagrams show the relative abundance of age groups discussed in Sect. 5. Samples associated with each unit are referenced in Table 1. Plot only shows ages from 0 to $1000 \mathrm{Ma}$; however, a small number of older ages were analyzed, and those data can be found in Table S1. $N$ : number of samples, number of ages depicted/total number of ages).

based on Pfiffner (2014), McCann (2008), Krawczyk et al. (2008), and Stephan et al. (2019a). While uncertainties and discordance of LA-ICP-MS U-Pb ages allow for overlap between these groupings, they provide a potential and viable way to depict and estimate detrital zircon contributions from these different source regions and to identify potential provenance changes in the Molasse Basin.

\section{Detrital zircon $\mathrm{U}-\mathrm{Pb}$ ages}

\subsection{Lucerne Section (central Switzerland; sample locations: Fig. 3a; U-Pb data: Fig. 4)}

For simplicity of data presentation, we grouped the detrital zircon $\mathrm{U}-\mathrm{Pb}$ ages according to their lithostratigraphic units as for most units there is only minor variation (no lacking or abundant age group changes between samples) in detrital zircon $\mathrm{U}-\mathrm{Pb}$ age signatures within individual units. For units that do display some variation between samples, we

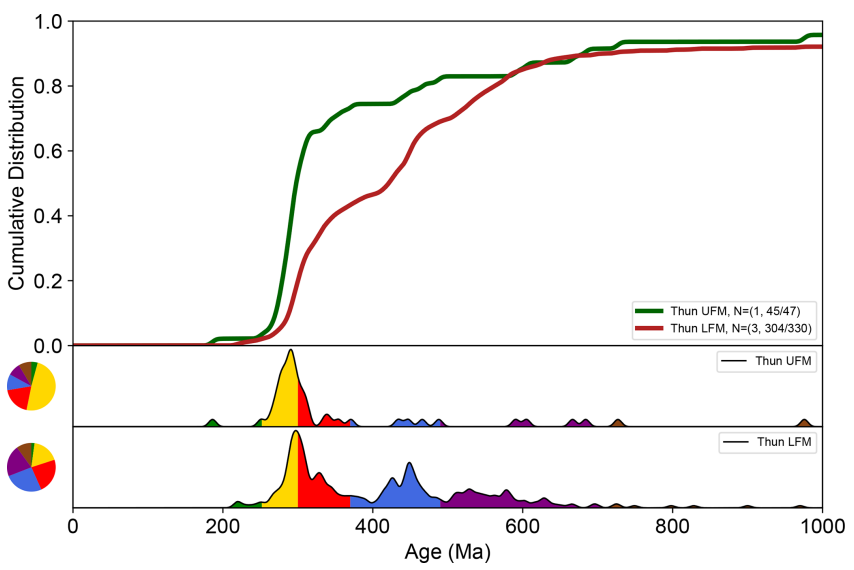

Figure 5. Detrital zircon U-Pb age data from the Thun Section (locations of samples depicted in Fig. 3b). See Fig. 4 legend and caption for additional information.

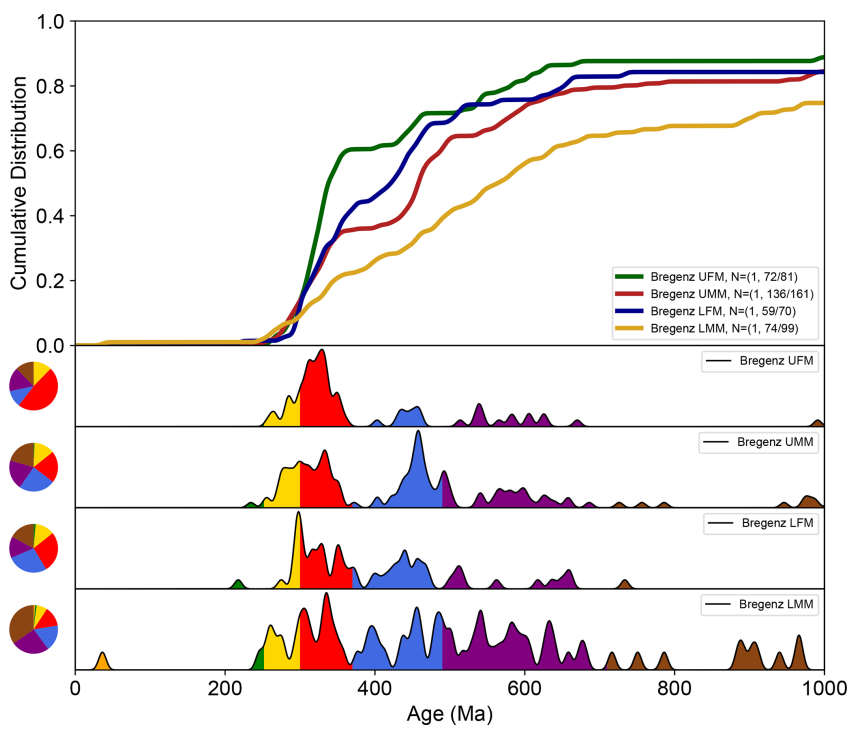

Figure 6. Detrital zircon $\mathrm{U}-\mathrm{Pb}$ age data from the Bregenz Section (locations of samples depicted in Fig. 3c). See Fig. 4 legend and caption for additional information.

note those changes in the sections below, and the detrital zircon U-Pb ages of individual samples can be found in Table S1. All associated sample information (i.e., location, depositional age, analyses performed, etc.) is located in Table 1.

\subsubsection{Northern Helvetic Flysch}

Samples 09SFB43 and 09SFB02 were collected from the Northern Helvetic Flysch and have a depositional age of $35 \pm 3 \mathrm{Ma}$. The samples contain a total of 261 concordant $\mathrm{U}-\mathrm{Pb}$ ages ranging from 34.8 to $2838 \mathrm{Ma}$ and can be binned in the following tectono-magmatic groups discussed in the Sect. 4: Cenozoic (4.2\%), Mesozoic (0.8\%), late Variscan $(9.6 \%)$, early Variscan $(5 \%)$, Caledonian $(29.1 \%)$, Cado- 
mian $(37.9 \%)$, and pre-Cadomian $(13.4 \%)$. Notably, there are 11 grains with ages between 34.8 and $37.3 \mathrm{Ma}$ in sample 09SFB43 that fall within the uncertainty of the depositional age.

\subsubsection{Lower Marine Molasse}

Sample 09SFB10b was collected from the Lower Marine Molasse and has a depositional age of $32 \pm 1 \mathrm{Ma}$. The sample contains a total of 114 concordant $\mathrm{U}-\mathrm{Pb}$ zircon ages ranging from 243.6 to $2611 \mathrm{Ma}$. There were no Cenozoic ages, two Mesozoic ages at 243.6 and 243.7 Ma and two Permian ages at 287.2 and 294.6. The age spectrum is composed of the following age groups with the following percentages: Mesozoic $(1.8 \%)$, late Variscan (1.8\%), early Variscan (17.5\%), Caledonian $(36 \%)$, Cadomian $(23.7 \%)$, and pre-Cadomian $(19.3 \%)$.

\subsubsection{Lower Freshwater Molasse}

Samples 09SFB45 and 09SFB21 were collected from the lower units of the Lower Freshwater Molasse and have depositional ages of $27 \pm 1 \mathrm{Ma}$ (LFM I) and $22.5 \pm 1 \mathrm{Ma}$ (LFM IIa), respectively. The combined samples contain a total of 202 concordant ages ranging from 191.7 to $2821 \mathrm{Ma}$. The sample yielded no Cenozoic grains and four Mesozoic grains with ages ranging from 191.7 to $243.1 \mathrm{Ma}$. The grains fall into the following age groups: Mesozoic (2\%), late Variscan $(9.4 \%)$, early Variscan $(13.9 \%)$, Caledonian $(25.7 \%)$, Cadomian $(26.2 \%)$, and Pre-Cadomian (19.3\%).

Samples 09SFB08, 09SFB13, and 09SFB33 were collected from Unit IIb of the Lower Freshwater Molasse and have depositional ages of $21 \pm 1,20.5 \pm 1$, and $20.5 \pm 1 \mathrm{Ma}$, respectively. The combined samples contain a total of 505 concordant $\mathrm{U}-\mathrm{Pb}$ analyses ranging in age from 222.7 to $2700 \mathrm{Ma}$. There were no Cenozoic ages and 11 Triassic ages ranging from 222.7 to $251.6 \mathrm{Ma}-9$ of these 11 grains had $>900 \mathrm{ppm} \mathrm{U}$ and were considered suspects for possible $\mathrm{Pb}$ loss. The age spectrum is composed of the following age groups and proportions: Mesozoic (2\%), late Variscan $(53.3 \%)$, early Variscan $(10.5 \%)$, Caledonian $(15.0 \%)$, Cadomian (11.7\%), and Pre-Cadomian (7.3\%).

\subsubsection{Upper Marine Molasse}

Samples 09SFB05, 09SFB29, 09SFB49, and 09SFB14 were collected from the Upper Marine Molasse and have depositional ages of $20 \pm 1,19 \pm 1,19 \pm 1$, and $17.5 \pm 1 \mathrm{Ma}$, respectively. These combined samples contain a total of 357 concordant ages ranging in age from 162.1 to 2470 Ma. There are no Cenozoic grains, 2 Jurassic ages (162.1 and $165.9 \mathrm{Ma}$ ), and 17 Triassic ages that range from 210.7 to 251.6 Ma. Overall, theses ages fall into the following groups: Mesozoic $(5.3 \%)$, late Variscan (41.1\%), early Variscan $(14.3 \%)$, Caledonian (13.8\%), Cadomian (15.7\%), and PreCadomian $(6.7 \%)$.

\subsubsection{Upper Freshwater Molasse}

Samples 09SFB12, 09SFB07, 09SFB11, and 09SFB38 were all collected from the Upper Freshwater Molasse and have depositional ages of $16 \pm 1,15.5 \pm 1,14 \pm 1$, and $13.5 \pm 1 \mathrm{Ma}$, respectively. These combined samples contain a total of 363 concordant ages ranging from 30.6 to $3059.9 \mathrm{Ma}$ and yielded a single Cenozoic age (30.6 Ma), a single Cretaceous age (130.7 Ma), a single Jurassic age (148.3 Ma), and 14 Triassic ages that range from 207.8.7 to $251.7 \mathrm{Ma}$. Overall, the age groups are characterized by the following proportions: Cenozoic $(0.3 \%)$, Mesozoic $(4.4 \%)$, late Variscan $(36 \%)$, early Variscan $(20 \%)$, Caledonian (18.4\%), Cadomian $(14 \%)$, and Pre-Cadomian $(6.9 \%)$.

\subsection{Thun Section (western to central Switzerland; sample locations: Fig. 3b; U-Pb data: Fig. 5)}

\subsubsection{Lower Freshwater Molasse}

Samples 13SFB03, 13SFB04, and 10SMB06 were collected from the Lower Freshwater Molasse and have depositional ages of $28 \pm 0.5,26 \pm 0.5$, and $22 \pm 2.5 \mathrm{Ma}$, respectively. The combined samples contain a total of 330 concordant ages ranging from 217.8 to $3304 \mathrm{Ma}$, falling into the following age groups: Mesozoic (2\%), late Variscan (18\%), early Variscan $(23 \%)$, Caledonian $(26.2 \%)$, Cadomian $(20.9 \%)$, and PreCadomian $(9.9 \%)$.

\subsubsection{Terrestrial equivalents of the Upper Marine Molasse and Upper Freshwater Molasse}

Sample 10SMB07 was collected from the terrestrial equivalent of the Upper Marine Molasse and Upper Freshwater Molasse and has a depositional age of $18 \pm 3 \mathrm{Ma}$. A large number of grains were discordant and hence the sample yielded only a total of 47 concordant ages ranging from 186.1 to $2688.2 \mathrm{Ma}$. The age groups represented were Mesozoic $(3.8 \%)$, late Variscan $(49.1 \%)$, early Variscan $(22.6 \%)$, Caledonian $(9.4 \%)$, Cadomian (7.5\%), and Pre-Cadomian $(7.5 \%)$.

\subsection{Bregenz Section (western Austria; sample locations: Fig. 3c; U-Pb data: Fig. 6)}

\subsubsection{Lower Marine Molasse}

Sample 10SMB12 was collected from the Lower Marine Molasse and has a depositional age of $32 \pm 2 \mathrm{Ma}$. The sample contains a total of 99 concordant ages ranging from 36.3 to $2702 \mathrm{Ma}$. It was characterized by the age groups and percentages: Cenozoic (1\%), Mesozoic (1\%), late Variscan (7.1\%), early Variscan (13.3\%), Caledonian (17.3\%), Cadomian (25.5\%), and Pre-Cadomian (34.7\%). It was remarkable that there was an anomalously large percentage of Mesoproterozoic $(11.2 \%)$ and Paleoproterozoic (12.2\%) ages. 


\subsubsection{Lower Freshwater Molasse}

Sample 10SMB11 was collected from the Lower Freshwater Molasse and has a depositional age of $22 \pm 2 \mathrm{Ma}$. The sample contains a total of 70 concordant ages ranging from 217.5 to $2172 \mathrm{Ma}$, falling into the following groups with the following percentages: Mesozoic (1.4\%), late Variscan (12.9\%), early Variscan (27.1\%), Caledonian (27.1\%), Cadomian (14.3\%), and Pre-Cadomian (17.1\%).

\subsubsection{Upper Marine Molasse}

Sample 10SMB10 was collected from the Upper Marine Molasse and has a depositional age of $19 \pm 2 \mathrm{Ma}$. The sample contains a total of 161 concordant ages ranging from 234.3 to $2837 \mathrm{Ma}$. It is characterized by the following age groups and percentages: Mesozoic (0.8\%), late Variscan (13.7\%), early Variscan (21.1\%), Caledonian (24.2\%), Cadomian (19.9\%), and Pre-Cadomian (20.5\%).

\subsubsection{Upper Freshwater Molasse}

Sample 10SMB09 was collected from the Upper Freshwater Molasse and has a depositional age of $15 \pm 2 \mathrm{Ma}$. The sample contains a total of 81 concordant ages ranging from 257.7.3 to $2030 \mathrm{Ma}$, characterized by the following age groups and percentages: late Variscan (12.3\%), early Variscan $(48.1 \%)$, Caledonian (11.1\%), Cadomian (16\%), and Pre-Cadomian (12.3\%). Notably, the sample lacks Cenozoic and Mesozoic detrital zircon.

\section{Detrital zircon geochemistry and rim-core relationships}

Individual zircon grains often record multiple growth episodes in response to magmatic or metamorphic events within a single source terrane. Recovery of these multi-event source signatures from a single zircon allows for improved pinpointing of detrital provenance and a more complete understanding of the source terrane history. LASS depth profiling by ICP-MS has enabled a more systematic harvesting of these relationships and hence a complete picture of the growth of the detrital zircon grains (e.g., Anfinson et al., 2016; Barber et al., 2019). We applied this methodology to samples of the Lucerne Section following the analytical procedures of Marsh and Stockli (2015) and Soto-Kerans et al. (2020). For discussion purposes, these data were divided into two groups: (1) depositional ages older than $21 \mathrm{Ma}$ and (2) depositional ages younger than $21 \mathrm{Ma}$. For depositional ages younger than $21 \mathrm{Ma}$, the geochemical data were drawn from the REE analyses of four samples (approximate depositional age in parentheses): 09SFB33 (20.5 Ma), 09SFB49 (19 Ma). 09SFB14 (17.5 Ma), and 09SFB38 (13.5 Ma). For depositional ages older than $21 \mathrm{Ma}$, the geochemical data were drawn from samples 09SFB45 (27 Ma) and 09SFB21
(22.5 Ma). Detrital zircon grains that have experienced hydrothermal alteration or contamination of the zircon profile by exotic mineral inclusion (e.g., apatite) commonly show high, flat LREE patterns (Hoskin and Ireland, 2000; Bell et al., 2019). We have removed these altered profiles from Fig. 7 but show all data in Table S2.

\subsection{Depositional ages older than $21 \mathrm{Ma}$}

The REE data show that Variscan detrital zircons are mainly magmatic in origin as indicted by comparison to REE profiles from Belousova et al. (2002) and Hoskin and Ireland (2000). There is little to no evidence for metamorphic or metasomatic zircon grains (Fig. 7a). In contrast, Cadomian and in particular Caledonian zircon grains exhibit elevated U-Th values (Fig. 8b). Only a single Caledonian grain with a $468 \mathrm{Ma} \mathrm{U}-\mathrm{Pb}$ age (sample SFB21) is characterized by a depleted heavy rare-earth element (HREE) profile (Fig. 7c) indicative of metamorphic growth in the presence of garnet (e.g., Rubatto, 2002). There is little evidence of mafic zircon sources, as the U parts per million and TE values are typically more characteristic of arc magmatism (e.g., Grimes et al., 2015; Barber et al., 2019). For depositional ages older than $21 \mathrm{Ma}$ there is a minor number of Variscan rims on Cadomian and Caledonian cores (Fig. 9).

\subsection{Depositional ages younger than $21 \mathrm{Ma}$}

Similar to the pre-Miocene detrital zircon, LASS-ICP-MS geochemical data from the younger stratigraphic samples (younger than $21 \mathrm{Ma}$ ) suggest that Variscan detrital zircons are primarily of magmatic origin. However, compared to the older samples, there is evidence for increasing input of metamorphic or metasomatic grains (Fig. 7b). Sample 09SFB14 contained one Variscan grain (262 Ma U-Pb age) and the youngest Molasse sample (09SFB38; ca. $13.5 \mathrm{Ma}$ ) three Variscan zircons (316-329 Ma) with depleted HREE profiles. 09SFB38 also has a higher percentage of Variscan grains with elevated U/Th values (Fig. 8a). Together, these data indicate a slight increase in the input of metamorphic Variscan sources through time. However, there is no evidence for the input of magmatic or metamorphic Alpine zircons or zircon rims.

The geochemical data of Caledonian and Cadomian detrital zircons from these Miocene samples also are consistent with a primarily magmatic origin with a subordinate number of detrital zircon grains exhibiting elevated $\mathrm{U} / \mathrm{Th}$ values (Fig. 8b). However, there is little evidence for metamorphic grains from the REE profiles (Fig. 7d).

Overall, the vast majority of all detrital zircon grains are interpreted as having a typical magmatic REE profile, with positive $\mathrm{Ce}$ and negative $\mathrm{Eu}$ anomalies, and overall positive slopes, including positive middle rare-earth element (MREE)-HREE slopes. The U/Th from all detrital zircon grains are consistent with predominately magmatic charac- 

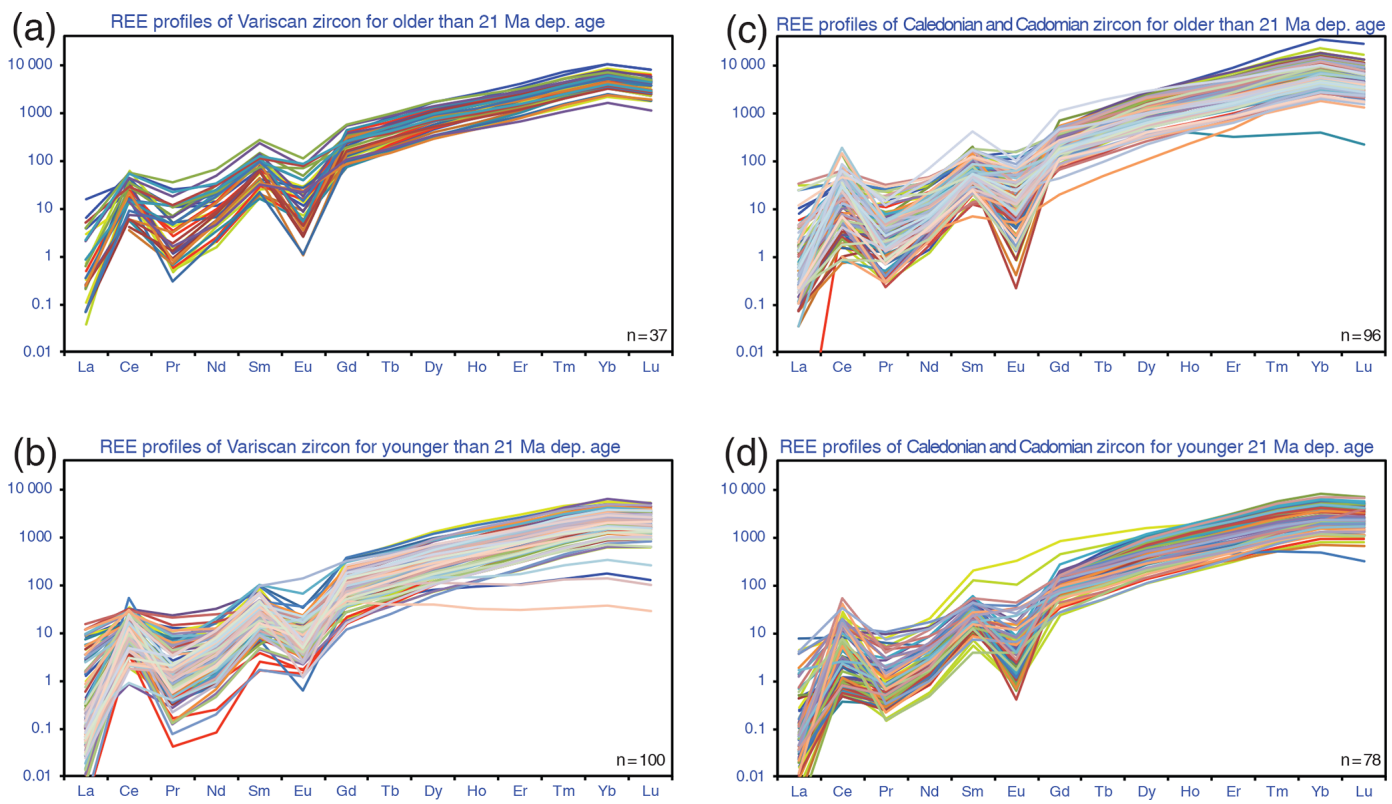

Figure 7. Detrital zircon rare-earth element (REE) spider diagram for samples collected from the Lucerne Section. (a) Variscan U-Pb ages and REE data for samples older than a 21 Ma depositional age and (b) younger than a 21 Ma depositional age. (c) Caledonian and Cadomian $\mathrm{U}-\mathrm{Pb}$ ages and $\mathrm{REE}$ data for samples older than a $21 \mathrm{Ma}$ depositional age and (d) younger than a 21 Ma depositional age. For (a) and (c) the geochemical data are drawn from samples SFB21 (22.5 Ma) and SFB45 (27 Ma). For (b) and (d) the geochemical data are drawn from samples SFB33 (20.5 Ma), SFB49 (19 Ma), SFB14 (17.5 Ma), and SFB38 (13.5 Ma). $n$ is the number of REE profiles available. The data suggest that detrital zircons from all three recent orogenic cycles record primarily grains that are magmatic in origin (Belousova et al., 2002; Hoskin and Ireland, 2000). However, there are an increased number $(n=4)$ of flat HREE profiles (indicative of a metamorphic origin; Rubatto, 2002) for Variscan grains from strata younger than $21 \mathrm{Ma}$. Data can be found in Table S2.

ters. In summary, the REE data suggest that detrital zircons from all recent orogenic cycles are primarily magmatic in origin with very limited metamorphic zircon input. For depositional ages younger than $21 \mathrm{Ma}$ there is a noticeable increase in Variscan rims on Caledonian, Cadomian, and older Proterozoic cores (Fig. 9).

\section{Discussion}

Erosion scenarios for the Alps that emphasize the importance of tectonic exhumation of the Lepontine dome have previously been proposed on the basis of provenance signals in the Molasse Basin, such as detrital zircon fission track data or detrital zircon and epidote geochemistry. These data and lines of evidence were synthesized by Spiegel et al. (2004). These reconstructions, however, have been based on a combination of various provenance indicators and at a relatively low temporal resolution in the Molasse Basin. This study leverages a detailed zircon $\mathrm{U}-\mathrm{Pb}$ and trace element dataset that focuses on foreland basin strata due north of the Lepontine dome with samples collected at high $(<1 \mathrm{Myr})$ temporal stratigraphic resolution. Hence, the observed changes in the detrital zircon $\mathrm{U}-\mathrm{Pb}$ age patterns in the Molasse Basin of central Switzerland provide direct constraints on the tectonic and exhumational evolution of the Central Alps and its drainage network, as well as insights into the Oligo-Miocene driving forces during the Alpine orogenesis between $\sim 23$ and $18 \mathrm{Ma}$. This interval is marked by a shift in provenance and the first arrival of a Lepontine dome source signal in the Molasse Basin (Spiegel et al., 2004; Boston et al., 2017). A similar shift has been documented in the southern Alpine foredeep with a shift from Caledonian to Variscan zircons derived from the exhuming Toce and Ticino culminations of the Lepontine dome at 23-24 Ma (Malusà et al., 2016). For comparison purposes with the sediment source region, detrital zircon age spectra from three modern river samples (Toce at Masera, Ticino at Belinzona, and Ticino at Bereguardo) derived from the Lepontine dome (Malusà et al., 2013) are depicted in Fig. 1. The age spectra provide some indication of what is currently being sourced from the Toce and Ticino sub-domes of the Lepontine dome. Comparison of these age spectra with the $\mathrm{U}-\mathrm{Pb}$ age data presented are considered with caution, as these ages are an indication of the presently exposed source region within the Lepontine dome and do not precisely represent the source region during time of deposition of the studied Molasse Basin strata.

In the Lucerne Section, the pertinent observation is a salient shift in the detrital zircon $\mathrm{U}-\mathrm{Pb}$ age signatures at $\sim 21 \mathrm{Ma}$. Prior to that time, detrital zircon ages included the entire range of pre-Cadomian, Cadomian, Caledonian, and 

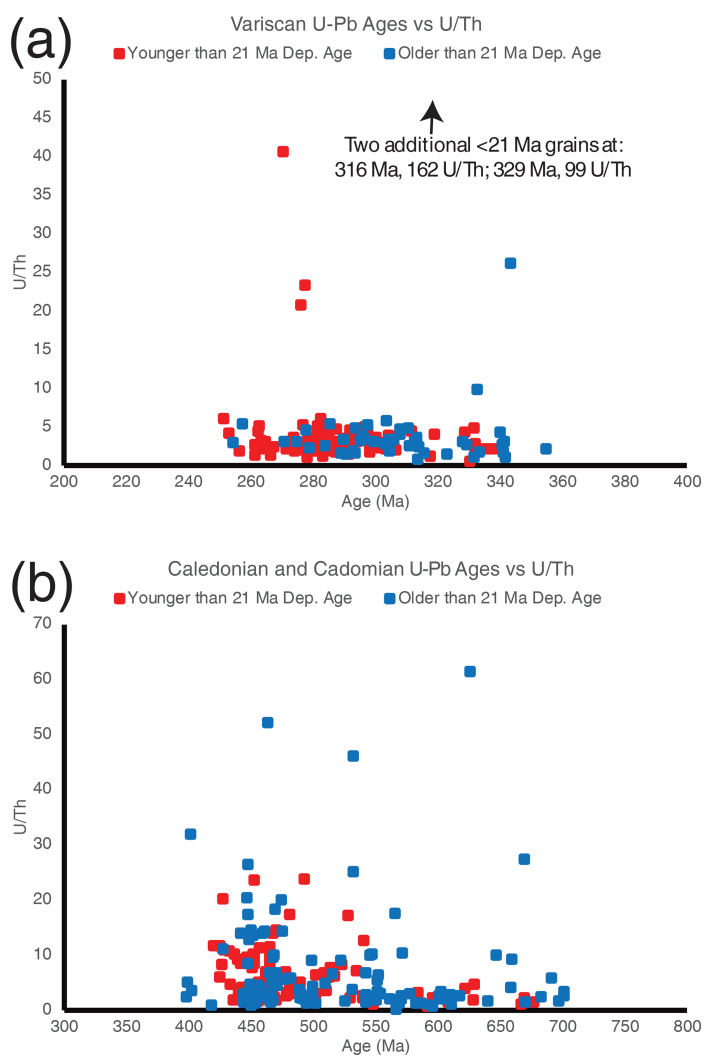

Figure 8. Age vs. U/Th comparison for detrital zircon grains with depositional ages older than $21 \mathrm{Ma}$ and younger than $21 \mathrm{Ma}$. (a) Variscan aged grains; (b) Caledonian and Cadomian age grains. Although not definitive, grains with elevated U/Th (or low Th/U; e.g., Rubatto et al., 2002) have a higher likelihood of being metamorphic in origin. There are few Variscan grains with elevated $\mathrm{U} / \mathrm{Th}$ from both the pre- and post-21 Ma depositional ages, suggesting little input of metamorphic sources for these ages. There are a large number of Caledonian and a handful of Cadomian grains with elevated U/Th from both the pre- and post-21 Ma depositional ages, indicating the metamorphic sources for these age grains are prevalent.

Variscan ages in similar proportions with little variation in zircon age patterns from sample to sample in the Molasse strata (Fig. 4). These age spectra are similar to the Malusà et al. (2013) sample from the Adda River (Fig. 1) that is primarily sourced from Austroalpine cover units. The occurrence of $\sim 34$ Ma detrital zircon in the North Helvetic Flysch sample 09SFB43 is noteworthy; these ages are essentially contemporaneous with the depositional age and make up $\sim 8 \%$ of the detrital zircon grains (Fig. 4). If Alpine age detrital zircon was present in other Molasse Basin samples, it would have been identified due to the depth-profile analytical approach (where rims can easily be recognized during data reduction). The lack of these Alpine ages in the Molasse sediments and the lack of these ages in modern river sediments (e.g., Krippner and Bahlburg, 2013) suggest that the drainage divide has

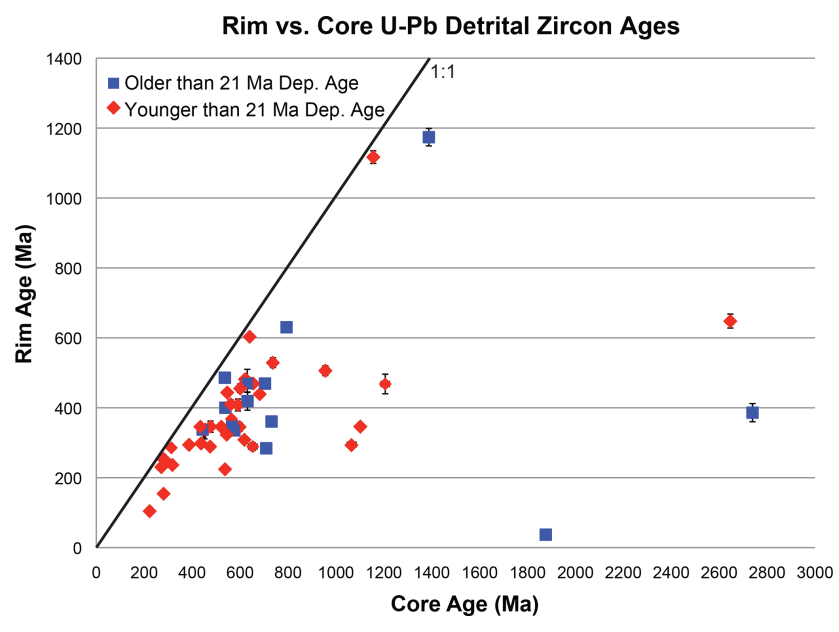

Figure 9. Rim vs. core ages for detrital zircon grains from samples with depositional ages older than $21 \mathrm{Ma}$ and younger than $21 \mathrm{Ma}$ from the Lucerne Section. Prior to the $21 \mathrm{Ma}$ transition in the source area, there is a minor number of Variscan rims on Cadomian and Caledonian cores. In samples younger than $21 \mathrm{Ma}$ there is a noticeable increase in Variscan rims on Caledonian, Cadomian, and Proterozoic cores. Error bars are $2 \sigma$ non-propagated errors.

likely remained north of Tertiary intrusives exposed along the Periadriatic Lineament.

In contrast to underlying strata, after $21 \mathrm{Ma}$, detrital zircon ages are dominated by late Variscan ages and limited contributions of older detrital zircon grains. The trend of increasing late Variscan ages is nicely depicted in the multidimensional scaling plot (MDS) of Fig. 10. Figure 10 compares the statistical similarity of the samples to one another utilizing an MDS plot with pie diagrams (generated using the DetritalPy software of Sharman et al., 2018b, and based on methods described in Vermeesch, 2018). This change in age pattern is rather abrupt and was likely accomplished within 1 Myr. The zircon REE chemistry data (Figs. 7 and 8) suggest that the bulk of the detrital zircon grains in the Cenozoic Molasse strata were primarily derived from magmatic or meta-magmatic rocks. However, after $\sim 21 \mathrm{Ma}$ there appears to have been a slight increase in the input of Variscan and Caledonian metamorphic sources. The age spectra after $21 \mathrm{Ma}$ correlate well with the modern river detrital zircon age spectra from the Toce River and Ticino River (at Bereguardo), providing further evidence for a correlation with sources within the Lepontine dome.

In the next section, we present a scenario of how the abrupt change at $21 \mathrm{Ma}$ can possibly be linked to the tectonic exhumation of the region surrounding the Lepontine dome, the most likely sediment source for the central Swiss Molasse (Schlunegger et al., 1998; von Eynatten et al., 1999). This provenance scenario, presented in chronological order, also includes consideration of the apparent first-cycle zircon grains ( $\sim 34 \mathrm{Ma})$ encountered in the Eocene North Helvetic Flysch. The provenance of the detrital zircon grains is 


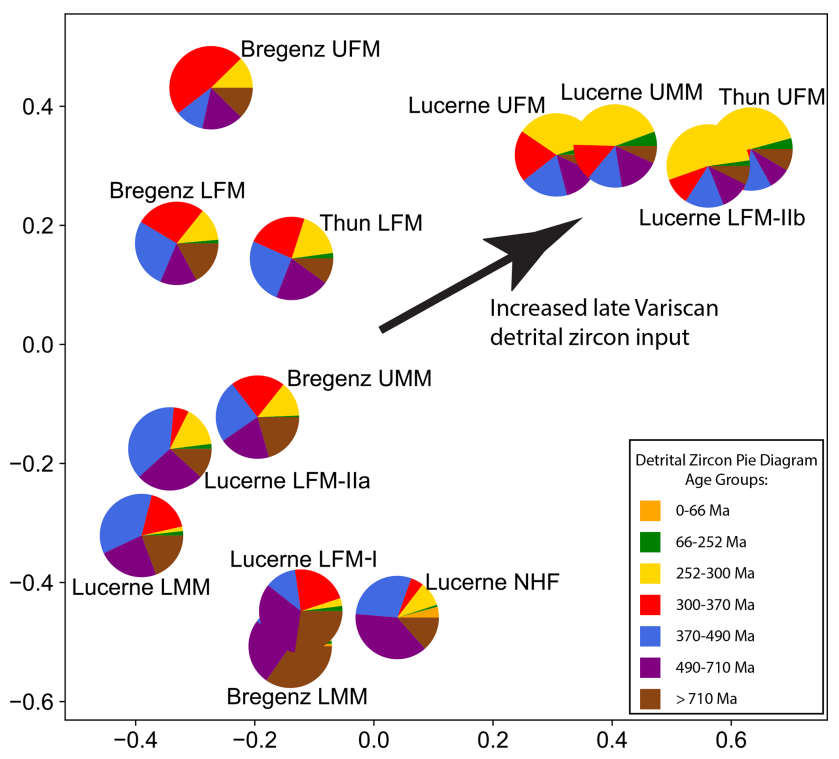

Figure 10. Multidimensional scaling plot (MDS) of detrital zircon $\mathrm{U}-\mathrm{Pb}$ ages for all units from the Molasse Basin. The MDS plot was produced with the DetritalPy software of Sharman et al. (2018b) and is based on methods outlined by Vermeesch (2018). Pie diagram colors correspond to age groups discussed in Sect. 5 .

thus discussed within a geodynamic framework of the Alpine Orogeny.

\subsection{Eocene drainage divide during the deposition of the North Helvetic Flysch}

The subduction of the European plate beneath the Adriatic plate began in the Late Cretaceous and was associated with the closure of the Tethys and Valais oceans (Schmid et al., 1996). The subducted material mainly included Tethyan oceanic crust, parts of the Valais oceans, and continental crustal slivers of the Briannçonnais or Iberian microcontinent (Schmid et al., 1996; Kissling and Schlunegger, 2018). The introduction of the European plate into the subduction channel resulted in high-pressure metamorphic overprints of these rocks. Subduction of the oceanic crust resulted in the down-warping of the European plate and the formation of the flysch trough, where clastic turbidites sourced from the erosion of the Adriatic orogenic lid were deposited in a deepmarine trench on the distal European plate (Sinclair et al., 1997). This also includes the volcano-clastic material of the Taveyannaz sandstone (Sinclair et al., 1997; Lu et al., 2018) and the related $34 \mathrm{Ma}$ first-cycle volcanic zircon grains encountered in the Eocene North Helvetic Flysch. Hence, while arc magmatism was situated on the Adriatic continental upper plate, volcaniclastic material was shed into the flysch trough on the European continental margin. This implies that during flysch sedimentation, the $\mathrm{N}-\mathrm{S}$ drainage divide was likely situated somewhere within the Adriatic upper-plate margin.

\subsection{Abrupt Oligo-Miocene detrital zircon U-Pb provenance shift}

Between 35 and $32 \mathrm{Ma}$, buoyant material of the European continental crust entered the subduction channel (Schmid et al., 1996; Handy et al., 2010). Strong tensional forces between the dense and subducted oceanic European lithosphere and the buoyant European continental crust possibly resulted in the break-off of the oceanic plate. As a result, the European plate experienced a phase of rebound and uplift, which was accomplished by back-thrusting along the Periadriatic Lineament (Schmid et al., 1989) and progressive ductile thrusting and duplexing of the deeper Penninic domain (e.g., Wiederkehr et al., 2009; Steck et al., 2013). Although this model has recently been challenged based on zircon $\mathrm{U}-\mathrm{Pb}$ and $\mathrm{Hf}$ isotopic compositions from the Tertiary Periadriatic intrusives (Ji et al., 2019), it still offers the most suitable explanation of the Alpine processes during the Oligocene (Kissling and Schlunegger, 2018). In response, the topographic and drainage divide shifted farther north to the locus of back-thrusting. Streams re-established their network and eroded the Alpine topography through headward retreat, thereby rapidly eroding and downcutting into deeper crustal levels from the Austroalpine cover nappes and into the Penninic units (Fig. 11a; Schlunegger and Norton, 2013). This is indicated by an increase in crystalline clasts in the conglomerates of the Lower Freshwater Molasse (Gasser, 1968; Stürm, 1973), and it is reflected by the detrital zircon U-Pb ages characterized by a cosmopolitan spectrum that spans the entire spread from Cadomian and older to late Variscan zircon grains (Fig. 10).

Surface uplift and progressive erosional unroofing also resulted in a steadily increasing sediment flux into the Molasse Basin (Kuhlemann, 2000; Willett, 2010) and a continuous increase in plutonic and volcanic clasts in the conglomerates (Stürm, 1973; Kempf et al., 1999) throughout the Oligocene (Fig. 11b). However, this pattern fundamentally changed at $\sim 22-20$ Ma when rapid slip along the Simplon fault occurred (Schlunegger and Willett, 1999), resulting in the rapid exhumation of the Lepontine dome as recorded by currently exposed rocks (Fig. 11c; Boston et al., 2017). Although thermal modeling and heavy-mineral thermochronometric data imply that the fastest cooling occurred between $\sim 20$ and $15 \mathrm{Ma}$ (Campani et al., 2010; Boston et al., 2017), tectonic exhumation likely started prior to this time interval given the lag time of isotherm perturbations at upper crustal levels (Schlunegger and Willet, 1999). In contrast to Schlunegger et al. (1998), von Eynatten et al. (1999) and Spiegel et al. (2000, 2001) suggested, on the basis of detrital mica ${ }^{40} \mathrm{Ar} /{ }^{39} \mathrm{Ar}$ age patterns and zircon cooling ages of detrital material, that slip along the Simplon normal fault did not result in a major change in the Alpine drainage organization and that the Lepontine dome was still a major sediment source for the Molasse Basin even after the period of rapid updoming and exhumation. In the Lucerne Section, contemporaneous 


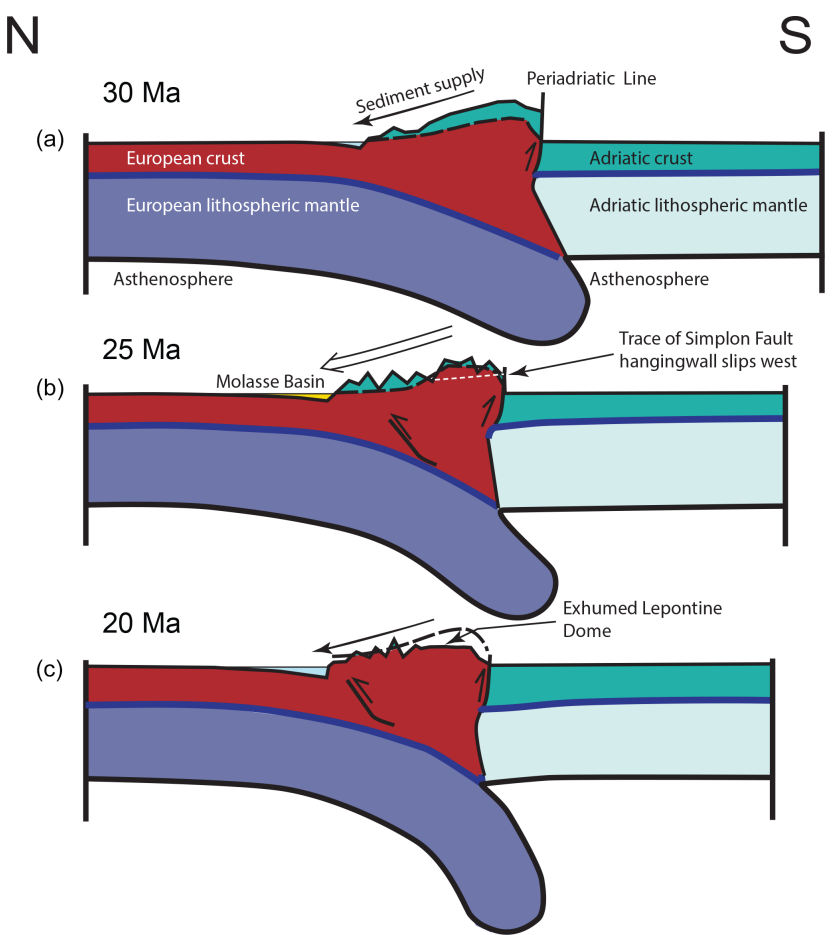

Figure 11. Schematic cross section through the Central Alps of Switzerland, illustrating the development of the Alpine relief and the topography through time. (a) At 30-25 Ma: slab break-off resulted in back-thrusting along the Periadriatic fault and in the growth of the Alpine topography. The erosional hinterland was mainly made up of the Austroalpine cover nappes (Adriatic plate) and Penninic sedimentary rocks at the orogen front. (b) At $25 \mathrm{Ma}$ : ongoing surface erosion resulted in the formation of an Alpine-type landscape with valleys and mountains. The first dissection into the crystalline core of the European continental plate was registered by the first arrival of Penninic crystalline material in the foreland basin sometime between 25 and $21 \mathrm{Ma}$, depending on the location within the basin. This was also the time when sediment discharge to the Molasse was highest. Tectonic exhumation through slip along the Simplon fault started to occur at the highest rates. (c) At $20 \mathrm{Ma}$ : tectonic exhumation along the Simplon fault resulted in widespread exposure of high-grade rocks, in a shift in the clast suites of the conglomerates and in a change in the detrital zircon age signatures. Faulting along the detachment fault most likely subdued the topography in the hinterland. As a result, sediment flux to the Molasse Basin decreased, and the basin became underfilled and was occupied by the peripheral sea of the Upper Marine Molasse (figures based on restored sections by Schlunegger and Kissling, 2015).

changes included (i) a shift in the petrographic composition of conglomerates with igneous constituents starting to dominate the clast suite (Schlunegger et al., 1998), (ii) a shift toward predominance of epidote in the heavy-mineral spectra (Gasser, 1966) with sources from nappes beneath the detachment faults (Spiegel et al., 2002), (iii) a continuous decrease in sediment discharge (Kuhlemann, 2000) paired with a fining-upward trend in the 21-20 Ma fluvial sediments of the LFM (Schlunegger et al., 1997a), and (iv) a return from terrestrial (LFM) back to marine (UMM) sedimentation at $\sim 20$ Ma within an underfilled flexural foreland basin (Keller, 1989; Garefalakis and Schlunegger, 2019). Our new detrital zircon $\mathrm{U}-\mathrm{Pb}$ ages exhibit an abrupt shift towards detrital zircon signatures dominated by Variscan zircons (Fig. 10), supporting the earlier notion of erosion of deeper crustal levels in response to tectonic exhumation (Spiegel et al., 2004). Because the Lucerne Section was situated due north of the Lepontine dome, and since this area was a major source of sediment for the Molasse Basin even after this phase of rapid tectonic exhumation (von Eynatten et al., 1999; Spiegel et al., 2004), we consider that these detrital zircon grains were most likely sourced from this part of the Central Alps. The shift to predominantly Variscan age zircon grains in UFM deposits is also observed in the western Swiss Molasse Basin (Thun Section; Figs. 5 and 10), which hosts conglomerates and sandstone that were derived both from the footwall and the hanging wall of the Simplon detachment fault (Matter, 1964; Schlunegger et al., 1993; von Eynatten et al., 1999; von Eynatten and Wijbrans, 2003). A similar related signal was also identified in the axial drainage of the Molasse $\sim 200 \mathrm{~km}$ farther east in the submarine Basal Hall Formation ( $20 \mathrm{Ma})$ (Sharman et al., 2018a).

In contrast to the conspicuous absence of Alpine detrital zircon $\mathrm{U}-\mathrm{Pb}$ ages in all of our samples, several studies have documented abundant Alpine detrital white mica cooling ages in nearby sections of the Honegg-Napf alluvial fan (von Eynatten and Wijbrans, 2003). They showed that while Cretaceous and younger white mica ages are widespread in Upper Penninic and lower Austroalpine units of the Alps, white mica ages <30 Ma can only be derived from below the Simplon detachment fault and the eroded upper part of the Lepontine dome as rocks in the hanging wall display white mica ages generally in the 35-45 Ma range. On the basis of these Alpine white mica ages, von Eynatten and Wijbrans (2003) invoked a sedimentary provenance from the Lepontine dome. This is also supported by abundant early Permian detrital mica ages, which are rare in Austroalpine units, and a clear shift in white mica chemistry consistent with a transition from granitic to metamorphic white mica. This apparent discrepancy between zircon and mica ages can likely be explained by the fact that during initial unroofing of the Lepontine dome only greenschist-facies rocks with reset mica ages were eroded, while deeper, high-grade portions of the Lepontine metamorphic dome, characterized by Alpine zircon growth, were not exposed until $<10-15 \mathrm{Ma}$ (Schlunegger and Willett, 1999; Boston et al., 2017). Hence, the lack of Alpine aged zircon growth in lower-grade Penninic rocks makes detrital zircon analysis less sensitive to the initial phases of Lepontine dome unroofing. 


\subsection{Constraints on surface exhumation of external massifs}

It has been suggested that rapid rock uplift of the external Aar Massif (Fig. 1), which is in close proximity to the Thun and Lucerne sections, likely started at $\sim 20 \mathrm{Ma}$ (Herwegh et al., 2017, 2019). However, we do not see a related signal in the detrital zircon $\mathrm{U}-\mathrm{Pb}$ age patterns (Fig. 10). Zircon $\mathrm{U}-\mathrm{Pb}$ ages from the Aar Massif primarily correspond to the early Variscan or Caledonian or Sardic (Schaltegger, 1993, 1994; Olsen et al., 2000; Schaltegger et al., 2003). The dominance of late Variscan detrital zircon ages in post-21 Ma strata of the Swiss Molasse Basin implies the Aar Massif is not a source of sediment.

Based on geochemical data of detrital garnet, Stutenbecker et al. (2019) showed that the first crystalline material of the Alpine external massifs became exposed to the surface no earlier than $\sim 14 \mathrm{Ma}$, with the consequence that related shifts were not detected in the zircon age populations. In fact, low-temperature thermochronometric data from the Aar and Mont Blanc massifs (e.g., Vernon et al., 2009; Glotzbach et al., 2011) document a major exhumation phase of the external massifs in the latest Miocene and early Pliocene, likely related to out-of-sequence thrusting and duplexing at depth. It is therefore likely, that surface exposure of the external massifs might not have occurred until the late Miocene to early Pliocene.

\subsection{Continuous detrital-zircon age evolution in the eastern Molasse Basin}

The detrital zircon ages of the sediments collected in the eastern region of the Swiss Molasse (Bregenz Section; Figs. 1 and 3c) show a shift where the relative abundance of Variscan material continuously increased through time (Figs. 6 and 10). The material of this region was derived from the eastern Swiss Alps, which includes the Austroalpine units, and possibly the eastern portion of the Lepontine dome (Kuhlemann and Kempf, 2002). This area was not particularly affected by tectonic exhumation (Schmid et al., 1996). Therefore, we interpret the continuous change in the age populations as a record of a rather normal unroofing sequence into the Alpine edifice. These interpretations are consistent with $\mathrm{Ar}^{40} / \mathrm{Ar}^{39}$ detrital white mica ages and detrital zircon fission track data collected from a nearby section that record progressive unroofing and no major tectonic pulses (von Eynatten et al., 2007). This continuous erosional unroofing is likely the result of erosional downcutting progressing from the Austroalpine sedimentary cover into its crystalline basement rocks, and eventually into Penninic ophiolites at $\sim 21$, as suggested by the occurrence of chrome spinel (von Eynatten, 2003).

\subsection{Tectonic exhumation and relationships to decreasing sediment flux}

The overall decrease in sediment discharge, which contributed to the transgression of the Upper Marine Molasse (Garefalakis and Schlunegger, 2019), could be related to the tectonic exhumation of the Lepontine dome. In particular, slip along the Simplon detachment fault resulted in the displacement of a ca. $10 \mathrm{~km}$ thick stack of rock units within a few million years (Schlunegger and Willett, 1999; Campani et al., 2010). A mechanism such as this is expected to leave a measurable impact on a landscape, which possibly includes (i) a reduction in the overall topography in the region of the footwall rocks (provided not all removal of rock was compensated for by uplift), (ii) a modification and thus a perturbation of the landscape morphometry, particularly in the footwall of a detachment fault (Pazzaglia et al., 2007), and (iii) exposure of rock with a higher metamorphic grade and thus a lower bedrock erodibility (Kühni and Pfiffner, 2001). We lack quantitative data to properly identify the main driving force and therefore consider that the combination of these three effects possibly contributed to an overall lower erosional efficiency of the Alpine streams, with the consequence that sediment flux to the Molasse decreased for a few million years. We thus use these mechanisms, together with the larger subsidence (Garefalakis and Schlunegger, 2019), to explain the shallowing-upward fluvial deposition in the post-21 Ma LFM IIb and the transgression of the UMM. Low sediment supply prevailed until steady-state erosional conditions were re-established during deposition of the UFM, as implied by the increase in sediment discharge to pre-20 Ma conditions towards the end of the UMM (Kuhlemann, 2000).

\section{Conclusions}

High-resolution detrital zircon provenance data from the Northern Alpine Molasse Basin show dominant Oligoceneearly-Miocene input from Austroalpine cover and basement nappes containing reworked detritus from Variscan, Caledonian-Sardic, Cadomian, and Pan-African orogenic cycles. Erosion was mainly driven by continuous unroofing and dissection into the Alpine edifice during uplift of the orogenic lid driven by the duplexing of the Penninic basement (e.g., Wiederkehr et al., 2009). However, during the deposition of the LFM, starting at $\sim 21 \mathrm{Ma}$, detrital zircon $\mathrm{U}-\mathrm{Pb}$ data exhibit decreasing sedimentary input from Austroalpine units and progressive unroofing and erosion into structurally lower Penninic nappes. Increased sourcing from Penninic units is signaled by a marked increase in Permian detrital zircon ages (252-300 Ma) in early Miocene foreland deposits, indicative of the exhumation of Variscanaged crystalline rocks from upper-Penninic basement units. This abrupt change in the detrital zircon age signatures in the early Miocene reflected a fundamental provenance shift 
in the Central Swiss Molasse corresponding to a phase of syn-orogenic extension and rapid tectonic exhumation of the Lepontine dome. This detrital zircon provenance shift temporally coincides with the arrival of reset Alpine white mica ${ }^{40} \mathrm{Ar} /{ }^{39} \mathrm{Ar}$ ages, derived from lower-grade, structurally higher portions of the Lepontine dome in the footwall of the Simplon detachment fault (von Eyanatten and Wijbrans, 2003). These two independent datasets clearly demonstrate an early Miocene provenance shift in response to the unroofing of metamorphic rocks in the upper portions of the Lepontine dome during orogen-parallel extension. However, no Alpine zircons were exhumed during this initial phase of unroofing of the Penninic core of the Central Alps, as highgrade, structurally lower levels of the Lepontine dome were not exhumed until the middle and late Miocene. In contrast, Oligo-Miocene Molasse sedimentary strata that were derived from the eastern margin of the Lepontine dome area (the Bregenz Section), show a more continuous exhumation history of the Alpine tectonic edifice with little evidence for accelerated tectonic exhumation, as is observed north of Penninic units in the Lepontine dome (Thun and Lucerne sections).

Surprisingly, this phase of rapid tectonic exhumation of the Lepontine dome and unroofing appears to temporally coincide with a decrease in sediment supply to the Molasse Basin, the re-establishment of shallow marine conditions, and fining-upward trend in deposition. This might be explained by a shift towards a less erosive landscape where tectonic exhumation, driven by orogen-parallel syn-orogenic extension resulted in a reduction in relief and exposure of metamorphic Penninic rocks with low erodibility.

Data availability. Due to the nature of the $\mathrm{U}-\mathrm{Pb}$ and geochemistry data (LASS and depth-profiled), the data have been included in the Supplement.

Supplement. Table S1: all depth-profiled detrital zircon U-Pb data. Table S2: all geochemistry data from LASS analysis. These geochem data also include the associated ages from Table S1. The supplement related to this article is available online at: https://doi.org/10.5194/se-11-2197-2020-supplement.

Author contributions. As primary author OAA collected samples, analyzed samples at UTchron, led the writing of the paper, and assembled collaborators. DFS collected a number of the samples, analyzed some samples with JCM and AM at the University of Kansas, helped analyze samples at UTchron, and aided in the writing of the paper. JCM collected a number of the samples with DFS, wrote his Master's Thesis at KU on the U-Pb and (U-Th)/He at KU, and aided in the writing of the paper. AM was advisor to JCM at KU during his masters work; he analyzed a number of the U-Pb samples at KU, and aided in the writing of the paper. FS helped with sample collection, met for a field trip in Switzerland, provided ex- pertise on the Molasse and Alpine Orogen, and aided in the writing of the paper.

Competing interests. The authors declare that they have no conflict of interest.

Acknowledgements. Thanks to the Jackson School of Geoscience at the University of Texas at Austin and to Sonoma State University for financial support. We would like to thank Lisa Stockli and Des Patterson for help with laboratory work at UTChron. Thanks to Andrew Smye, Jeff Marsh, Ryan Mackenzie, and Shannon Loomis and for extensive discussion of the data and interpretations and to the editor Kei Ogata. The content of the paper was drastically improved based on reviews by Jan Wijbrans, Hilmar von Eynatten, Laura Stutenbecker, and an anonymous reviewer.

Review statement. This paper was edited by Kei Ogata and reviewed by Hilmar von Eynatten, Jan Wijbrans, Laura Stutenbecker, and one anonymous referee.

\section{References}

Allen, M., Saville, C., Blanc, E. P., Talebian, M., and Nissen, E.: Orogenic plateau growth: Expansion of the Turkish-Iranian Plateau across the Zagros fold-and-thrust belt, Tectonics, 32, 171-190, 2013.

Allen, P. A., Mange-Rajetzky, M., Matter, A., and Homewood, P.: Dynamic paleogeography of the open Burdigalian seaway, Swiss Molasse basin, Eclogae Geol. Helv., 78, 351-381, 1985.

Allen, P. A., Crampton, S. L., and Sinclair, H. D.: The inception and early evolution of the North Alpine Foreland Basin, Switzerland, Basin Res., 3, 143-163, 1991.

Andersen, T.: Correction of common lead in $\mathrm{U}-\mathrm{Pb}$ analyses that do not report ${ }^{204} \mathrm{~Pb}$, Chem. Geol., 192, 59-79, 2002.

Anfinson, O. A., Malusà, M. G., Ottria, G., Dafov, L. N., and Stockli, D. F.: Tracking coarse-grained gravity flows by LASSICP-MS depth-profiling of detrital zircon (Aveto Formation, Adriatic foredeep, Italy), Mar. Petrol. Geol., 77, 1163-1176, 2016.

Barber, D. E., Stockli, D. F., and Galster, F.: The Proto-Zagros Foreland Basin in Lorestan, Western Iran: Insights From Multimineral Detrital Geothermochronometric and Trace Elemental Provenance Analysis, Geochem. Geophy. Geosy., 20, 26572680, 2019.

Beck, P. und Rutsch, R. F.: Geol. Atlasblatt 21 (1:25,000) Münsingen-Konolfingen-Gerzensee-Heimberg, Schweiz, Geol. Komm., 1949.

Bell, E. A., Boehnke, P., Barboni, M., and Harrison, T. M.: Tracking chemical alteration in magmatic zircon using rare earth element abundances, Chem. Geol., 510, 56-71, 2019.

Belousova, E., Griffin, W. L., O'Reilly, S. Y., and Fisher, N.: Igneous zircon: trace element composition as an indicator of source rock type, Contrib. Mineral. Petr., 143, 602-622, 2002. 
Bernet, M., Zattin, M., Garver, J. I., Brandon, M. T., and Vance, J. A.: Steady-state exhumation of the European Alps, Geology, 29, 35-38, 2001.

Bernet, M., Brandon, M., Garver, J., Balestieri, M., Ventura, B., and Zattin, M.: Exhuming the Alps through time: Clues from detrital zircon fission-track thermochronology, Basin Res., 21, 781-798, 2009.

Boston, K. R., Rubatto, D., Hermann, J., Engi, M., and Amelin, Y.: Geochronology of accessory allanite and monazite in the Barrovian metamorphic sequence of the Central Alps, Switzerland, Lithos, 286, 502-518, 2017.

Büchi, U. P. and Schlanke, S.: Zur paläogeographie der schweizerischen Molasse, Erdöl-Erdgas-Zeitschrift, 93, 57-69, 1977.

Burkhard, M. and Sommaruga, A.: Evolution of the western Swiss Molasse basin: structural relations with the Alps and the Jura belt, Geological Society, London, Special Publications, 134, 279-298, 1998.

Bütler, E., Winkler, W., and Guillong, M.: Laser ablation U/Pb age patterns of detrital zircons in the Schlieren Flysch (Central Switzerland): new evidence on the detrital sources, Swiss J. Geosci., 104, 225-236, https://doi.org/10.1007/s00015-0110065-1, 2011.

Campani, M., Herman, F., and Mancktelow, N.: Two-and three-dimensional thermal modeling of a low-angle detachment: Exhumation history of the Simplon Fault Zone, central Alps, J. Geophys. Res.-Sol. Ea., 115, B10420, https://doi.org/10.1029/2009JB007036, 2010.

Carrapa, B.: Tracing exhumation and orogenic wedge dynamics in the European Alps with detrital thermochronology, Geology, 37, 1127-1130, 2009.

Carrapa, B.: Tracing exhumation and orogenic wedge dynamics in the European Alps with detrital thermochronology: REPLY, Geology, 38, e227-e227, https://doi.org/10.1130/G31644Y.1, 2010.

Cederbom, C. E., Sinclair, H. D., Schlunegger, F., and Rahn, M. K.: Climate-induced rebound and exhumation of the European Alps, Geology, 32, 709-712, 2004.

Cederbom, C. E., Van Der Beek, P., Schlunegger, F., Sinclair, H. D., and Oncken, O.: Rapid extensive erosion of the North Alpine foreland basin at 5-4 Ma, Basin Res., 23, 528-550, 2011.

Crampton, S. and Allen, P.: Recognition of forebulge unconformities associated with early stage foreland basin development: example from the North Alpine Foreland Basin, AAPG Bull., 79, 1495-1514, 1995.

Davis, J. H. and von Blanckenburg, F.: Slab breakoff: A model of lithosphere detachment and its test in the magmatism and deformation of collisional orogens, Earth Planet. Sc. Lett., 129, 85$102,1995$.

DeCelles, P. G. and Giles, K. A.: Foreland basin systems, Basin Res., 8, 105-123, 1996.

Dewey, J. and Horsfield, B.: Plate tectonics, orogeny and continental growth, Nature, 225, 521-525, 1970.

Diem, B.: Die Untere Meeresmolasse zwischen der Saane (Westschweiz) und der Ammer (Oberbayern), Eclogae. Geol. Helv., 79, 493-559, 1986.

Dietrich, V.: Die Oberhalbsteiner Talbildung im Tertiär: ein Vergleich zwischen den Ophiolithen und deren Detritus in der ostschweizerischen Molasse, Geologisches Institut der Eidg. Technischen Hochschule und der Universität, Zürich, 1969.
D'Lemos, R., Strachan, R., and Topley, C.: The Cadomian orogeny in the North Armorican Massif: a brief review, Geological Society, London, Special Publications, 51, 3-12, 1990.

Dunkl, I., Mikes, T., Frei, D., Gerdes, A., and von Eynatten, H.: PepiAGE data reduction program for time-resolved $\mathrm{U} / \mathrm{Pb}$ analyses - introduction and call for tests and discussion, University of Goettingen Publication, Goettingen, 15 pp., 2009.

Engesser, B. and Mayo, N. A.: A biozonation of the Lower Freshwater Molasse (Oligocene and Agenian) of Switzerland and Savoy on the basis of fossil mammals, Münchner Geowiss., 10, 67-84, 1987.

Engi, M., Todd, C., and Schmatz, D.: Tertiary metamorphic conditions in the eastern Lepontine Alps, Schweiz. Miner. Petrog., 75, 347-369, 1995.

Engi, M., Bousquet, R., and Berger, A.: Explanatory notes to the map: Metamorphic structure of the Alps-Central Alps, Mitteilungen der Österreichischen Mineralogischen Gesellschaft, 149, 157-173, 2004.

Finger, F., Roberts, M., Haunschmid, B., Schermaier, A., and Steyrer, H.-P.: Variscan granitoids of central Europe: their typology, potential sources and tectonothermal relations, Miner. Petrol., 61, 67-96, 1997.

Franke, W.: The Variscan orogen in Central Europe: construction and collapse, Geological Society, London, Memoirs, 32, 333343, 2006.

Frey, M., Teichmiiller, M., Teichmiiller, R., Mullis, J., Kfinzi, B., Breitschmid, A., Gruner, U., and Schwitzer, B.: Very low grade metamorphism in external parts of the Central Alps: Illite crystallinity, coal rank and fluid inclusion data, Eclogae. Geol. Helv., 73, 173-203, 1980.

Froitzheim, N., Schmid, S. M., and Frey, M.: Mesozoic paleogeography and the timing of eclogite-facies metamorphism in the Alps: a working hypothesis, Eclogae. Geol. Helv., 89, 81 pp., 1996.

Fry, B., Deschamps, F., Kissling, E., Stehly, L., and Giardini, D.: Layered azimuthal anisotropy of Rayleigh wave phase velocities in the European Alpine lithosphere inferred from ambient noise, Earth Planet. Sc. Lett., 297, 95-102, 2010.

Fûchtbauer, H.: Sedimentpetrographische Untersuchungen in der alteren Molasse nordlich der Alpen, Eclogae. Geol. Helv., 57, 157-298, 1964.

Garefalakis, P. and Schlunegger, F.: Link between concentrations of seidment flux and deep crustal processes beneath the European Alps, Sci. Rep.-UK, 8, 183, https://doi.org/10.1038/s41598-01717182-8, 2018.

Garefalakis, P. and Schlunegger, F.: Tectonic processes, variations in sediment flux, and eustatic sea level recorded by the $20 \mathrm{Myr}$ old Burdigalian transgression in the Swiss Molasse basin, Solid Earth, 10, 2045-2072, https://doi.org/10.5194/se-10-2045-2019, 2019.

Gasser, U.: Sedimentologische Untersuchungen in der äusseren Zone der subalpinen Molasse des Entlebuchs (Kt. Luzern), Eclogae geol. Helv. 59, 723-772, 1966.

Gasser, U.: Die innere Zone der subalpinen Molasse des Entlebuchs (Kt. Luzern), Eclogae geol. Helv., 61, 229-319, 1968.

Gebauer, D.: Alpine geochronology of the Central and Western Alps: new constraints for a complex geodynamic evolution, Schweiz. Miner. Petrog., 79, 191-208, 1999. 
Gebauer, D., Quadt, A., Compston, W., Williams, I., and Grünenfelder, M.: Archaean zircons in a retrograded, Caledonian eclogite of the Gotthard Massif (Central Alps, Switzerland), Schweiz. Miner. Petrog., 68, 485-490, 1988.

Glotzbach, C., Van Der Beek, P. A., and Spiegel, C.: Episodic exhumation and relief growth in the Mont Blanc massif, Western Alps from numerical modelling of thermochronology data, Earth Planet. Sc. Lett., 304, 417-430, 2011.

Grasemann, B. and Mancktelow, N. S.: Two-dimensional thermal modelling of normal faulting: the Simplon Fault Zone, Central Alps, Switzerland, Tectonophysics, 225, 155-165, 1993.

Grimes, C., Wooden, J., Cheadle, M., and John, B.: "Fingerprinting" tectono-magmatic provenance using trace elements in igneous zircon, Contrib. Mineral. Petr., 170, 46, https://doi.org/10.1007/s00410-015-1199-3, 2015.

Habicht, K.: Neuere Beobachtungen in der subalpinen Molasse zwischen Zugersee und dem st. gallischen Rheintal, Geologisches Institut der Eidg. Technischen Hochschule und der Universität, Zürich, 1945.

Handy, M. R., Schmid, S. M., Bousquet, R., Kissling, E., and Bernoulli, D.: Reconciling plate-tectonic reconstructions of Alpine Tethys with the geological-geophysical record of spreading and subduction in the Alps, Earth-Sci. Rev., 102, 121-158, 2010.

Hart, N. R., Stockli, D. F., and Hayman, N. W.: Provenance evolution during progressive rifting and hyperextension using bedrock and detrital zircon $\mathrm{U}-\mathrm{Pb}$ geochronology, Mauléon Basin, western Pyrenees, Geosphere, 12, 1166-1186, 2016.

Herwegh, M., Berger, A., Baumberger, R., Wehrens, P., and Kissling, E.: Large-scale crustal-block-extrusion during late Alpine collision, Sci. Rep.-UK, 7, 1-10, 2017.

Herwegh, M., Berger, A., Glotzbach, C., Wangenheim, C., Mock, S., Wehrens, P., Baumberger, R., Egli, D., and Kissling, E.: Late stages of continent-continent collision: Timing, kinematic evolution, and exhumation of the Northern rim (Aar Massif) of the Alps, Earth-Sci. Rev., 200, 102959, https://doi.org/10.1016/j.earscirev.2019.102959, 2019.

Hetényi, G., Molinari, I., Clinton, J., Bokelmann, G., Bondár, I., Crawford, W. C., Dessa, J.-X., Doubre, C., Friederich, W., and Fuchs, F.: The AlpArray seismic network: a large-scale European experiment to image the Alpine Orogen, Surv. Geophys., 39, 1009-1033, 2018.

Homewood P, Allen PA, Williams GD: Dynamics of the Molasse Basin of western Switzerland, in: Foreland basins, edited by: Allen, P. A. and Homewood, P., Int. Assoc. Sedimentol. Spec. Publ., 8, 199-217, 1986.

Hoskin, P. W.: Trace-element composition of hydrothermal zircon and the alteration of Hadean zircon from the Jack Hills, Australia, Geochim. Cosmochim. Ac., 69, 637-648, 2005.

Hoskin, P. W. and Ireland, T. R.: Rare earth element chemistry of zircon and its use as a provenance indicator, Geology, 28, 627630,2000

Hunziker, J. C., Desmons, J., and Hurford, A. J.: Thirty-two years of geochronological work in the Central and Western Alps: a review on seven maps, Mem. Geol. Lausanne, Lausanne, 13, 59 pp., 1992.

Hurford, A. J.: Cooling and uplift patterns in the Lepontine Alps South Central Switzerland and an age of vertical movement on the Insubric fault line, Contrib. Mineral. Petr., 92, 413-427, 1986.

Jackson, S. E., Pearson, N. J., Griffin, W. L., and Belousova, E. A.: The application of laser ablation-inductively coupled plasmamass spectrometry to in situ U-Pb zircon geochronology, Chem. Geol., 211, 47-69, 2004.

Ji, W. Q., Malusà, M. G., Tiepolo, M., Langone, A., Zhao, L., and Wu, F. Y.: Synchronous Periadriatic magmatism in the Western and Central Alps in the absence of slab breakoff, Terra Nova, 31, 120-128, 2019.

Jin, J., Aigner, T., Luterbacher, H., Bachmann, G. H., and Müller, M.: Sequence stratigraphy and depositional history in the southeastern German Molasse Basin, Mar. Petrol. Geol., 12, 929-940, 1995.

Jordan, T. and Flemings, P. B.: Large-scale stratigraphic architecture, eustatic variation, and unsteady tectonism: a theoretical evaluation, J. Geophys. Res.- Sol. Ea., 96, 6681-6699, 1991.

Jost, J., Kempf, O., and Kälin, D.: Stratigraphy and palaeoecology of the Upper Marine Molasse (OMM) of the central Swiss Plateau, Swiss J. Geosci, 109, 149-169, 2016.

Kälin, D. and Kempf, O.: High-resolution stratigraphy from the continental record of the Middle Miocene Northern Alpine Foreland Basin of Switzerland, Neues Jahrb. Geol. P.-A., 254, 177235, 2009.

Keller, B.: Fazies und Stratigraphie der Oberen Meeresmolasse (Unteres Miozän) zwischen Napf und Bodensee, $\mathrm{PhD}$ thesis, Universität Bern, Switzerland, 402 pp., 1989.

Keller, B.: Fazies der Molasse anhand eines Querschnitts durch das zentrale Schweizer Mittelland, Jber. Mitt. Oberrhein, 82, 55-92, 2000.

Kempf, O. and Matter, A.: Magnetostratigraphy and depositional history of the Upper Freshwater Molasse (OSM) of eastern Switzerland, Eclogae. Geol. Helv., 92, 97-103, 1999.

Kempf, O., Matter, A., Burbank, D., and Mange, M.: Depositional and structural evolution of a foreland basin margin in a magnetostratigraphic framework: the eastern Swiss Molasse Basin, Int. J. Earth Sci., 88, 253-275, 1999.

Kissling, E. and Schlunegger, F.: Rollback orogeny model for the evolution of the Swiss Alps, Tectonics, 37, 1097-1115, 2018.

Krawczyk, C., McCann, T., Cocks, L. R. M., England, R. W., McBride, J. H., and Wybraniec, S.: Caledonian tectonics, in: The Geology of Central Europe, edited by: McCann, T., 1, Precambrian and Paleozoic, Geological Society, London, 303-381, 2008.

Kröner, A. and Stern, R. J.: Pan-Aftrican Orogeny, Encyclopedia of Geology, 1, 1-12, 2004.

Krippner, A. and Bahlburg, H.: Provenance of Pleistocene Rhine River Middle Terrace sands between the Swiss-German border and Cologne based on U-Pb detrital zircon ages, Int. J. Earth Sci., 102, 917-932, 2013.

Kuhlemann, J.: Post-collisional sediment budget of circum-Alpine basins (Central Europe), Mem. Sci. Geol. Padova, 52, 1-91, 2000 .

Kuhlemann, J. and Kempf, O.: Post-Eocene evolution of the North Alpine Foreland Basin and its response to Alpine tectonics, Sediment. Geol., 152, 45-78, 2002.

Kühni, A. and Pfiffner, O.-A.: Drainage patterns and tectonic forcing: a model study for the Swiss Alps, Basin Res., 13, 169-197, 2001. 
Kylander-Clark, A. R. C., Hacker, B. R., and Cottle, J. M.: Laserablation split-stream ICP petrochronology, Chem. Geol., 345, 99-112, https://doi.org/10.1016/j.chemgeo.2013.02.019, 2013.

Laubscher, H.: Detachment, shear, and compression in the central Alps, Geol. Soc. Am. Mem, 158, 191-211, 1983.

Lihou, J. C. and Allen, P. A.: Importance of inherited rift margin structures in the early North Alpine Foreland Basin, Switzerland, Basin Res., 8, 425-442, 1996.

Lippitsch, R., Kissling, E., and Ansorge, J.: Upper mantle structure beneath the Alpine orogen from high-resolution teleseismic tomography, J. Geophys. Res.-Sol. Ea., 108, 2376, https://doi.org/10.1029/2002JB002016, 2003.

Lourens, L. J., Hilgen, F. J., Laskar, J., Shackleton, N. J., and Wilson, D.: The Neogene Period. A Geologic Time Scale 2004, Cambridge University Press, Cambridge, 409-440, 2004.

Lu, G., Winkler, W., Rahn, M., von Quadt, A., and Willett, S. D.: Evaluating igneous sources of the Taveyannaz formation in the Central Alps by detrital zircon U-Pb age dating and geochemistry, Swiss J. Geosci., 111, 399-416, 2018.

Mair, D., Lechmann, A., Herwegh, M., Nibourel, L., and Schlunegger, F.: Linking Alpine deformation in the Aar Massif basement and its cover units - the case of the Jungfrau-Eiger mountains (Central Alps, Switzerland), Solid Earth, 9, 1099-1122, https://doi.org/10.5194/se-9-1099-2018, 2018.

Malusà, M. G., Carter, A., Limoncelli, M., Villa, I. M., and Garzanti, E.: Bias in detrital zircon geochronology and thermochronometry, Chem. Geol., 359, 90-107, 2013.

Malusà, M. G., Anfinson, O. A., Dafov, L. N., and Stockli, D. F.: Tracking Adria indentation beneath the Alps by detrital zircon $\mathrm{U}-\mathrm{Pb}$ geochronology: Implications for the Oligocene-Miocene dynamics of the Adriatic microplate, Geology, 44, 155-158, https://doi.org/10.1130/G37407.1, 2016.

Mancktelow, N.: The Simplon Line: a major displacement zone in the western Lepontine Alps, Eclogae. Geol. Helv., 78, 73-96, 1985.

Mancktelow, N. S. and Grasemann, B.: Time-dependent effects of heat advection and topography on cooling histories during erosion, Tectonophysics, 270, 167-195, 1997.

Marsh, J. H. and Stockli, D. F.: Zircon U-Pb and trace element zoning characteristics in an anatectic granulite domain: Insights from LASS-ICP-MS depth profiling, Lithos, 239, 170-185, 2015.

Matter, A.: Sedimentologische Untersuchungen im östlichen Napfgebiet (Entlebuch-Tal der Grossen Fontanne, Kt. Luzern), Eclogae. Geol. Helv., 57, 315-428, 1964.

Matter, A., Homewood, P. W., Caron, C., Van Stuijvenberg, J., Weidmann, M., and Winkler, W.: Flysch and molasse of central and western Switzerland, in: Geology of Switzerland, a guide book, edited by: Trümpy, R., Schweiz. Geol. Komm., 261-293, 1980.

Mazurek, M., Hurford, A. J., and Leu, W.: Unravelling the multistage burial history of the Swiss Molasse Basin: integration of apatite fission track, vitrinite reflectance and biomarker isomerisation analysis, Basin Res., 18, 27-50, 2006.

McCann, T. (Ed.): The geology of central Europe, Geologial Society of London, London, United Kingdom, 2008.

Müller, B., Schaltegger, U., Klötzli, U., and Flisch, M.: Early Cambrian oceanic plagiogranite in the Silvretta nappe, eastern Alps: Geochemical, zircon $\mathrm{U}-\mathrm{Pb}$ and $\mathrm{Rb}-\mathrm{Sr}$ data from garnethornblende-plagioclase gneisses, Geol. Rundsch., 85, 822-831, 1996.
Neubauer, F.: Evolution of late Neoproterozoic to early Paleozoic tectonic elements in Central and Southeast European Alpine mountain belts: review and synthesis, Tectonophysics, 352, 87103, 2002.

Niggli, E. and Niggli, C.: Karten der Verbreitung einiger Mineralien der alpidischen Metamorphose in den Schweizer Alpen (Stilpnomelan, Alkali-Amphibol, Chloritoid, Staurolith, Disthen, Sillimanit), Eclogae. Geol. Helv., 58, 335-368, 1965.

Oberhauser, R.: 110 St. Galen Nord Und 111 Dornbern Nord, Geologische Bundesanstalt, Vienna, AT, 1994.

Olsen, S. N., Johnson, C. M., Beard, B. L., and Baumgartner, L. P.: New U-Pb zircon data and constraints on the age and mode of migmatization in the Aar massif, Central Alps, Eur. J. Mineral., 12, 1245-1260, 2000.

Paton, C., Woodhead, J. D., Hellstrom, J. C., Hergt, J. M., Greig, A., and Maas, R.: Improved laser ablation U-Pb zircon geochronology through robust downhole fractionation correction, Geochem. Geophy., 11, Q0AA06, https://doi.org/10.1029/2009GC002618, 2010.

Paton, C., Hellstrom, J., Paul, B., Woodhead, J., and Hergt, J.: Iolite: Freeware for the visualisation and processing of mass spectrometric data, J. Anal. Atom. Spectrom., 26, 2508-2518, 2011.

Pazzaglia, F. J., Selverstone, J., Roy, M., Steffen, K., NewlandPearce, S., Knipscher, W., and Pearce, J.: Geomorphic expression of midcrustal extension in convergent orogens, Tectonics, 26, TC6010, https://doi.org/10.1029/2006TC001961, 2007.

Petrus, J. A. and Kamber, B. S.: VizualAge: A Novel Approach to Laser Ablation ICP-MS U-Pb Geochronology Data Reduction, Geostand. Geoanal. Res., 36, 247-270, https://doi.org/10.1111/j.1751-908X.2012.00158.x, 2012.

Pfiffner, O. A.: Evolution of the north Alpine foreland basin in the Central Alps. Special Publication, Int. As. Sed., 8, 219-228, 1986.

Pfiffner, O. A.: Geology of the Alps, John Wiley \& Sons, New Jersey, 2014.

Pfiffner, O.-A., Schlunegger, F., and Buiter, S.: The Swiss Alps and their peripheral foreland basin: Stratigraphic response to deep crustal processes, Tectonics, 21, 3-1-3-16, https://doi.org/10.1029/2000TC900039, 2002.

Platt, N. H. and Keller, B.: Distal alluvial deposits in a foreland basin setting - the Lower Freshwater Miocene), Switzerland: sedimentology, architecture and palaeosols, Sedimentology, 39, 545-565, 1992.

Rahn, M., Mullis, J., Erdelbrock, K., and Frey, M.: Very lowgrade metamorphism of the Taveyanne greywacke, Glarus Alps, Switzerland, J. Metamorph. Geol., 12, 625-641, 1994.

Reichenwallner, S.: Die vulkanische Aktivität in den Westalpen hergeleitet aus detritischem Amphibol und Klinopyroxen im Taveyannaz-Sandstein, M.Sc. thesis, University of Bern, Switzerland, 57 pp., 2019.

Renz, H.: Die subalpine Molasse zwischen Aare und Rhein, Eclogae geol. Helv., 30, 87-214, 1937.

Ring, U.: The Alpine geodynamic evolution of Penninic nappes in the eastern Central Alps: geothermobarometric and kinematic data, J. Metamorph. Geol., 10, 33-53, 1992.

Rubatto, D.: Zircon trace element geochemistry: partitioning with garnet and the link between $\mathrm{U}-\mathrm{Pb}$ ages and metamorphism, Chem. Geol., 184, 123-138, 2002. 
Rubatto, D., Regis, D., Hermann, J., Boston, K., Engi, M., Beltrando, M., and McAlpine, S. R.: Yo-yo subduction recorded by accessory minerals in the Italian Western Alps, Nat. Geosci., 4, 338-342, 2011.

Schaad W., Keller, B., and Matter A.: Die Obere Meeresmolasse (OMM) am Pfänder: Beispiel eines Gilbert-Deltakomplexes, Eclogae. Geol. Helv., 85, 145-168, 1992.

Schaltegger, U.: The evolution of the polymetamorphic basement in the Central Alps unraveled by precise $\mathrm{U}-\mathrm{Pb}$ zircon dating, Contrib. Mineral. Petr., 113, 466-478, 1993.

Schaltegger, U.: Unravelling the pre-Mesozoic history of Aar and Gotthard massifs (Central Alps) by isotopic dating: a review: The pre-Alpine crustal evolution of the Aar-, Gotthard-and Tavetsch massifs, Schweiz. Miner. Petrog., 74, 41-51, 1994.

Schaltegger, U. and Gebauer, D.: Pre-Alpine geochronology of the central, western and southern Alps, Schweiz. Miner. Petr., 79, 79-87, 1999.

Schaltegger, U., Abrecht, J., and Corfu, F.: The Ordovician orogeny in the Alpine basement: constraints from geochronology and geochemistry in the Aar Massif (Central Alps), Swiss Bulletin of Mineralogy and Petrology, 83, 183-239, 2003.

Schegg, R., Cornford, C., and Leu, W.: Migration and accumulation of hydrocarbons in the Swiss Molasse Basin: implications of a 2D basin modeling study, Mar. Petrol. Geol., 16, 511-531, 1999.

Schlanke, S.: Geologie der Subalpinen Molasse Zwischen Biberbrugg SZ, Huetten ZH und Agerisee ZG, Schweiz, 1974.

Schlunegger, F. and Castelltort, S.: Immediate and delayed signal of slab breakoff in Oligo/Miocene Molasse deposits from the European Alps, Sci. Rep.-UK, 6, 31010, https://doi.org/10.1038/srep31010, 2016.

Schlunegger, F. and Kissling, E.: Slab rollback orogeny in the Alps and evolution of the Swiss Molasse basin, Nat. Commun., 6, 110, 2015.

Schlunegger, F. and Norton, K. P.: Water versus ice: The competing roles of modern climate and Pleistocene glacial erosion in the Central Alps of Switzerland, Tectonophysics, 602, 370-381, 2013.

Schlunegger, F. and Willett, S.: Spatial and temporal variations in exhumation of the central Swiss Alps and implications for exhumation mechanisms, Geol. Soc. Sp., 154, 157-179, 1999.

Schlunegger, F., Matter, A., and Mange, M. A.: Alluvial fan sedimentation and structure of the southern Molasse basin margin, Lake Thun area, Switzerland, Eclogae. Geol. Helv., 86, 717-750, 1993.

Schlunegger, F., Burbank, D. W., and Matter, A.: Magnetostratigraphic calibration of the Oligocence to Middle Miocene (30-15 Ma) mammal biozones and depositional sequences of the Swiss Molasse Basin, Eclogae. Geol. Helv., 89, 753-788, 1996.

Schlunegger, F., Matter, A., Burbank, D. W., and Klaper, E. M.: Magnetostratigraphic constraints on relationships between evolution of the central Swiss Molasse basin and Alpine orogenic events, Geol. Soc. Am. Bull., 102, 225-241, 1997a.

Schlunegger, F., Leu, W., and Matter, A.: Sedimentary sequences, seismic facies, subsidence analysis, and evolution of the Burdigalian Upper Marine Molasse Group, central Switzerland, AAPG Bull., 81, 1185-1207, 1997b.

Schlunegger, F., Matter, A., Burbank, D., Leu, W., Mange, M., and Matyas, J.: Sedimentary sequences, seismofacies and evolution of depositional systems of the Oligo/Miocene Lower Freshwater Molasse Group, Switzerland, Basin Res., 9, 1-26, 1997c.

Schlunegger, F., Slingerl, R., and Matter, A.: Crustal thickening and crustal extension as controls on the evolution of the drainage network of the central Swiss Alps between $30 \mathrm{Ma}$ and the present: constraints from the stratigraphy of the North Alpine Foreland Basin and the structural evolution of the Alps, Basin Res., 10, 197-212, 1998.

Schlunegger, F., Rieke-Zapp, D., and Ramseyer, K.: Possible environmental effects on the evolution of the AlpsMolasse Basin system, Swiss J. Geosci., 100, 383-405, https://doi.org/10.1007/s00015-007-1238-9, 2007.

Schmid, S., Aebli, H., Heller, F., and Zingg, A.: The role of the Periadriatic Line in the tectonic evolution of the Alps, Geological Society, London, Special Publications, 45, 153-171, 1989.

Schmid, S. M., Pfiffner, O. A., Froitzheim, N., Schönborn, G., and Kissling, E.: Geophysical-geological transect and tectonic evolution of the Swiss-Italian Alps, Tectonics, 15, 1036-1064, https://doi.org/10.1029/96tc00433, 1996.

Schmid, S. M., Fugenschuh, B., Kissling, E., and Schuster, R.: Tectonic map and overall architecture of the Alpine orogen, Eclogae. Geol. Helv., 97, 93-117, https://doi.org/10.1007/s00015004-1113-x, 2004.

Sharman, G. R., Hubbard, S. M., Covault, J. A., Hinsch, R., Linzer, H. G., and Graham, S. A.: Sediment routing evolution in the North Alpine Foreland Basin, Austria: interplay of transverse and longitudinal sediment dispersal, Basin Res., 30, 426-447, $2018 \mathrm{a}$.

Sharman, G. R., Sharman, J. P., and Sylvester, Z.: detritalPy: A Python-based toolset for visualizing and analysing detrital geothermochronologic data, The Depositional Record, 4, 202-215, 2018b.

Sinclair, H. and Allen, P.: Vertical versus horizontal motions in the Alpine orogenic wedge: stratigraphic response in the foreland basin, Basin Res., 4, 215-232, 1992.

Sinclair, H. D., Coakley, B. J., Allen, P. A., and Watts, A. B.: Simulation of foreland basin stratigraphy using a diffusion model of mountain belt uplift and erosion: An example from the Central Alps, Switzerland, Tectonics, 10, 599-620, 1991.

Sinclair, M. R., Wratt, D. S., Henderson, R. D., and Gray, W. R.: Factors affecting the distribution and spillover of precipitation in the Southern Alps of New Zealand - A case study, J. Appl. Meteorol., 36, 428-442, 1997.

Soto-Kerans, G. M., Stockli, D. F., Janson, X., Lawton, T. F., and Covault, J. A.: Orogen proximal sedimentation in the Permian foreland basin, Geosphere, 16, 567-593, 2020.

Spicher, A.: Tektonische Karte der Schweiz, Schweizerische Geologische Kommission Bern, Schweiz, 1980.

Spiegel, C., Kuhlemann, J., Dunkl, I., Frisch, W., von Eynatten, H., and Balogh, K.: The erosion history of the Central Alps: evidence from zircon fission track data of the foreland basin sediments, Terra Nova, 12, 163-170, 2000.

Spiegel, C., Kuhlemann, J., Dunkl, I., and Frisch, W.: Paleogeography and catchment evolution in a mobile orogenic belt: the Central Alps in Oligo-Miocene times, Tectonophysics, 341, 33-47, 2001.

Spiegel, C., Siebel, W., Frisch, W., and Berner, Z.: Nd and Sr isotopic ratios and trace element geochemistry of epidote from the Swiss Molasse Basin as provenance indicators: implications for 
the reconstruction of the exhumation history of the Central Alps, Chem. Geol., 189, 231-250, 2002.

Spiegel, C., Siebel, W., Kuhlemann, J., and Frisch, W.: Toward a comprehensive provenance analysis: A multi-method approach and its implications for the evolution of the Central Alps, Geol. Soc. Am. Spec. Paper, 378, 37-50, 2004.

Stampfli, G. M. and Borel, G. D.: A plate tectonic model for the Paleozoic and Mesozoic constrained by dynamic plate boundaries and restored synthetic oceanic isochrons, Earth Planet. Sc. Lett., 196, 17-33, https://doi.org/10.1016/S0012821x(01)00588-X, 2002.

Steck, A., Della Torre, F., Keller, F., Pfeifer, H.-R., Hunziker, J., and Masson, H.: Tectonics of the Lepontine Alps: ductile thrusting and folding in the deepest tectonic levels of the Central Alps, Swiss J. Geosci., 106, 427-450, 2013.

Steiger, R. H. and Jäger, E.: Subcommission on geochronology: convention on the use of decay constants in geo-and cosmochronology, Earth Planet. Sc. Lett., 36, 359-362, 1977.

Stephan, T., Kroner, U., Romer, R. L., and Rösel, D.: From a bipartite Gondwana shelf to an arcuate Variscan belt: The early Paleozoic evolution of northern Peri-Gondwana, Earth-Sci. Rev., 192, 491-512, 2019a.

Stephan, T., Kroner, U., and Romer, R. L.: The pre-orogenic detrital zircon record of the Peri-Gondwanan crust, Geol. Mag., 156, 281-307, 2019b.

Strunck, P. and Matter, A.: Depositional evolution of the western Swiss Molasse, Eclogae. Geol. Helv., 95, 197-222, 2002.

Stürm, B.: Die Rigischüttung. Sedimentpetrographie, Sedimentologie, Paläogeographie, Tektonik, $\mathrm{PhD}$ thesis, Universität Zürich, Switzerland, 98 pp., 1973.

Stutenbecker, L., Tollan, P. M. E., Madella, A., and Lanari, P.: Miocene basement exhumation in the Central Alps recorded by detrital garnet geochemistry in foreland basin deposits, Solid Earth, 10, 1581-1595, https://doi.org/10.5194/se-10-1581-2019, 2019.

Trail, D., Watson, E. B., and Tailby, N. D.: Ce and Eu anomalies in zircon as proxies for the oxidation state of magmas, Geochim. Cosmochim. Ac., 97, 70-87, 2012.

Vermeesch, P.: How many grains are needed for a provenance study?, Earth Planet. Sc. Lett., 224, 441-451, https://doi.org/10.1016/j.epsl.2004.05.037, 2004.

Vermeesch, P.: Dissimilarity measures in detrital geochronology, Earth-Sci. Rev., 178, 310-321, 2018.

Vernon, A. J., van der Beek, P. A., and Sinclair, H. D.: Spatial correlation between long-term exhumation rates and present-day forcing parameters in the western European Alps, Geology, 37, 859862,2009

von Eynatten, H.: Heavy minerals in the Swiss Molasse basin: occurrence, frequency, chemistry and thermochronology, Developments in Sedimentology, 58, 887-905, 2007. von Eynatten, H.: Petrography and chemistry of sandstones from the Swiss Molasse Basin: an archive of the Oligocene to Miocene evolution of the Central Alps, Sedimentology, 50, 703-724, 2003.

von Eynatten, H. and Dunkl, I.: Assessing the sediment factory: the role of single grain analysis, Earth-Sci. Rev., 115, 97-120, 2012.

von Eynatten, H. and Wijbrans, J.: Precise tracing of exhumation and provenance using ${ }^{40} \mathrm{Ar} /{ }^{39} \mathrm{Ar}$ geochronology of detrital white mica: the example of the Central Alps, Geological Society, London, Special Publications, 208, 289-305, 2003.

von Eynatten, H., Schlunegger, F., Gaupp, R., and Wijbrans, J. R.: Exhumation of the Central Alps: evidence from ${ }^{40} \mathrm{Ar} /{ }^{39} \mathrm{Ar}$ laserprobe dating of detrital white micas from the Swiss Molasse Basin, Terra Nova, 11, 284-289, 1999.

von Raumer, J.: The Palaeozoic evolution in the Alps: from Gondwana to Pangea, Geol. Rundsch., 87, 407-435, 1998.

von Raumer, J. F., Stampfli, G. M., Borel, G., and Bussy, F.: Organization of pre-Variscan basement areas at the north-Gondwanan margin, Int. J. Earth Sci., 91, 35-52, https://doi.org/10.1007/s005310100200, 2002.

von Raumer, J. F., Stampfli, G. M., and Bussy, F.: Gondwanaderived microcontinents - the constituents of the Variscan and Alpine collisional orogens, Tectonophysics, 365, 7-22, 2003.

von Raumer, J. F., Bussy, F., and Stampfli, G. M.: The Variscan evolution in the External massifs of the Alps and place in their Variscan framework, C. R. Geosci., 341, 239-252, 2009.

Watson, E., Wark, D., and Thomas, J.: Crystallization thermometers for zircon and rutile, Contrib. Mineral. Petr., 151, 413, 2006.

Wiederkehr, M., Sudo, M., Bousquet, R., Berger, A., and Schmid, S. M.: Alpine orogenic evolution from subduction to collisional thermal overprint: The ${ }^{40} \mathrm{Ar} /{ }^{39} \mathrm{Ar}$ age constraints from the Valaisan Ocean, central Alps, Tectonics, 28, TC6009, https://doi.org/10.1029/2009TC002496, 2009.

Willett, S. D.: Late Neogene erosion of the Alps: A climate driver?, Annu. Rev. Earth Pl. Sc., 38, 411-437, 2010.

Willett, S. D. and Schlunegger, F.: The last phase of deposition in the Swiss Molasse Basin: From foredeep to negative-alpha basin, Basin Res., 22, 623-639, 2010.

Zhong, S., Seltmann, R., Qu, H., and Song, Y.: Characterization of the zircon Ce anomaly for estimation of oxidation state of magmas: a revised Ce/Ce* method, Mineral. Petrol., 113, 755-763, 2019.

Zurbriggen, R.: The Cenerian orogeny (early Paleozoic) from the perspective of the Alpine region, Int. J. Earth Sci., 106, 517-529, 2017.

Zweigel, J., Aigner, T., and Luterbacher, H.: Eustatic versus tectonic controls on Alpine foreland basin fill: sequence stratigraphy and subsidence analysis in the SE German Molasse, Geological Society, London, Special Publications, 134, 299-323, 1998. 